San Jose State University

SJSU ScholarWorks

Master's Theses

Master's Theses and Graduate Research

1992

\title{
The effects of herbivorous gastropod species and densities on early algal succession in the high intertidal zone
}

John A. Tarpley

San Jose State University

Follow this and additional works at: https://scholarworks.sjsu.edu/etd_theses

\section{Recommended Citation}

Tarpley, John A., "The effects of herbivorous gastropod species and densities on early algal succession in the high intertidal zone" (1992). Master's Theses. 510.

DOI: https://doi.org/10.31979/etd.k5r4-6twu

https://scholarworks.sjsu.edu/etd_theses/510

This Thesis is brought to you for free and open access by the Master's Theses and Graduate Research at SJSU ScholarWorks. It has been accepted for inclusion in Master's Theses by an authorized administrator of SJSU ScholarWorks. For more information, please contact scholarworks@sjsu.edu. 

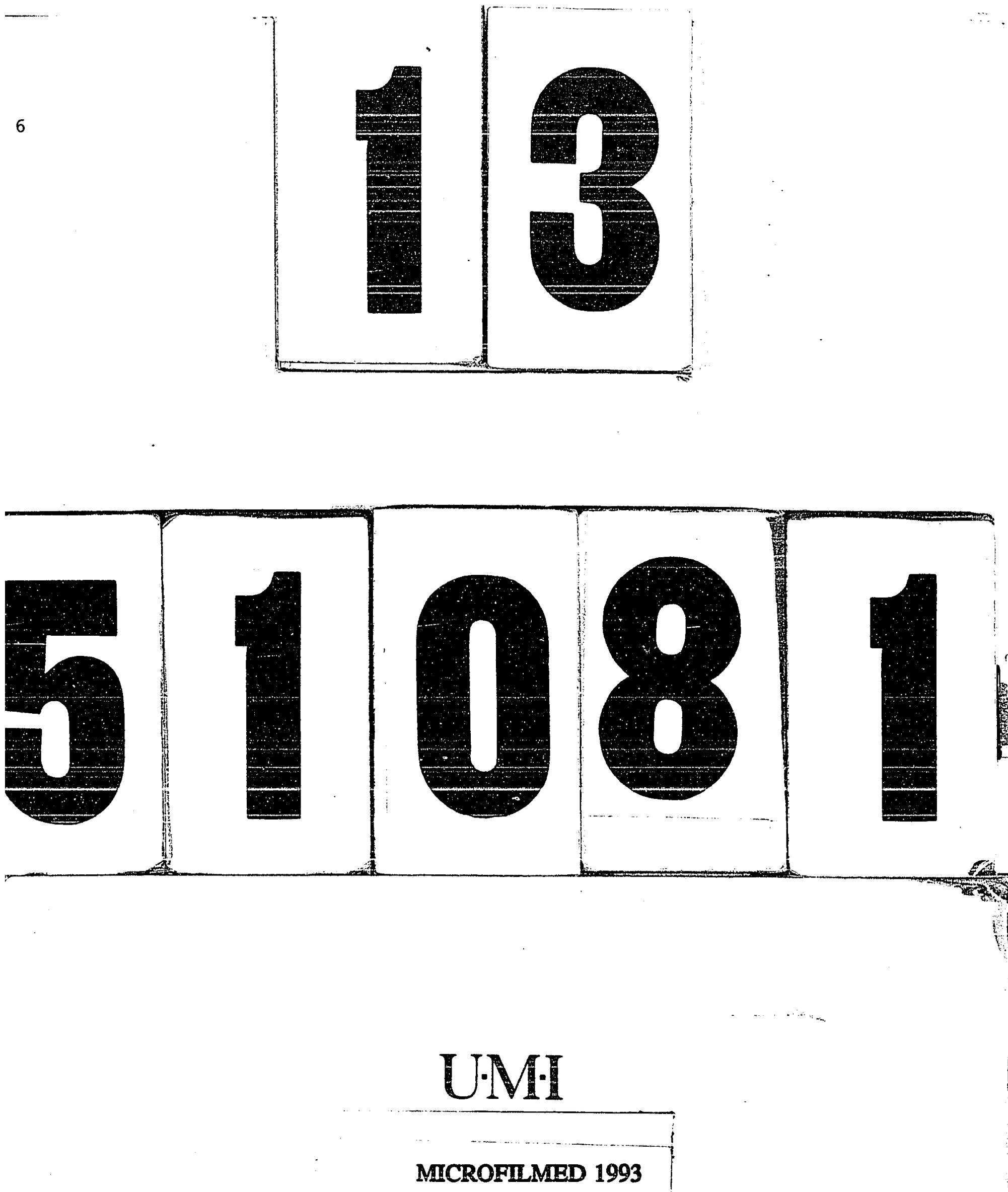


\section{INFORMATION TO USERS}

This manuscript has been reproduced from the microfilm master. UMI films the text directly from the original or copy submitted. Thus, some thesis and dissertation copies are in typewriter face, while others may be from any type of computer printer.

The quality of this reproduction is dependent upon the quality of the copy submitted. Broken or indistinct print, colored or poor quality illustrations and photographs, print bleedthrough, substandard margins, and improper alignment can adversely affect reproduction.

In the unlikely event that the author did not send UMI a complete manuscript and there are missing pages, these will be noted. Also, if unauthorized copyright material had to be removed, a note will indicate the deletion.

Oversize materials (e.g., maps, drawings, charts) are reproduced by sectioning the original, beginning at the upper left-hand corner and continuing from left to right in equal sections with small overlaps. Each original is also photographed in one exposure and is included in reduced form at the back of the book.

Photographs included in the original manuscript have been reproduced xerographically in this copy. Higher quality $6 " \times$ " 9 " black and white photographic prints are available for any photographs or illustrations appearing in this copy for an additional charge. Contact UMI directly to order.

\section{U.M.I}

University Microfilms International

A Bell \& Howell Information Company

300 North Zeeb Road. Ann Arbor. MI 48106-1346 USA

313:761-4700 800:521-0600 


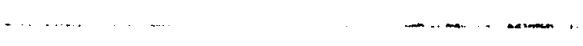


Order Number 1851081

The effects of herbivorous gastropod species and densities on early algal succession in the high intertidal zone

Tarpley, John A., M.S.

San Jose State University, 1992

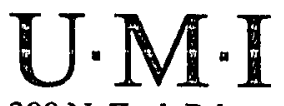

300 N. Zeeb Rd.

Ann Arbor, MI 48106 

THE EFFECTS OF HERBIVOROUS GASTROPOD

\title{
SPECIES AND DENSITIES ON EARLY ALGAL SUCCESSION
}

IN THE HIGH INTERTIDAL ZONE

\author{
A Thesis \\ Presented to the Faculty \\ of \\ Moss Landing Marine Laboratories \\ San Jose State University \\ In Partial Fulfillment \\ of the Requirements for the Degree \\ Master of Science
}

By

John A. Tarpley

December, 1992 


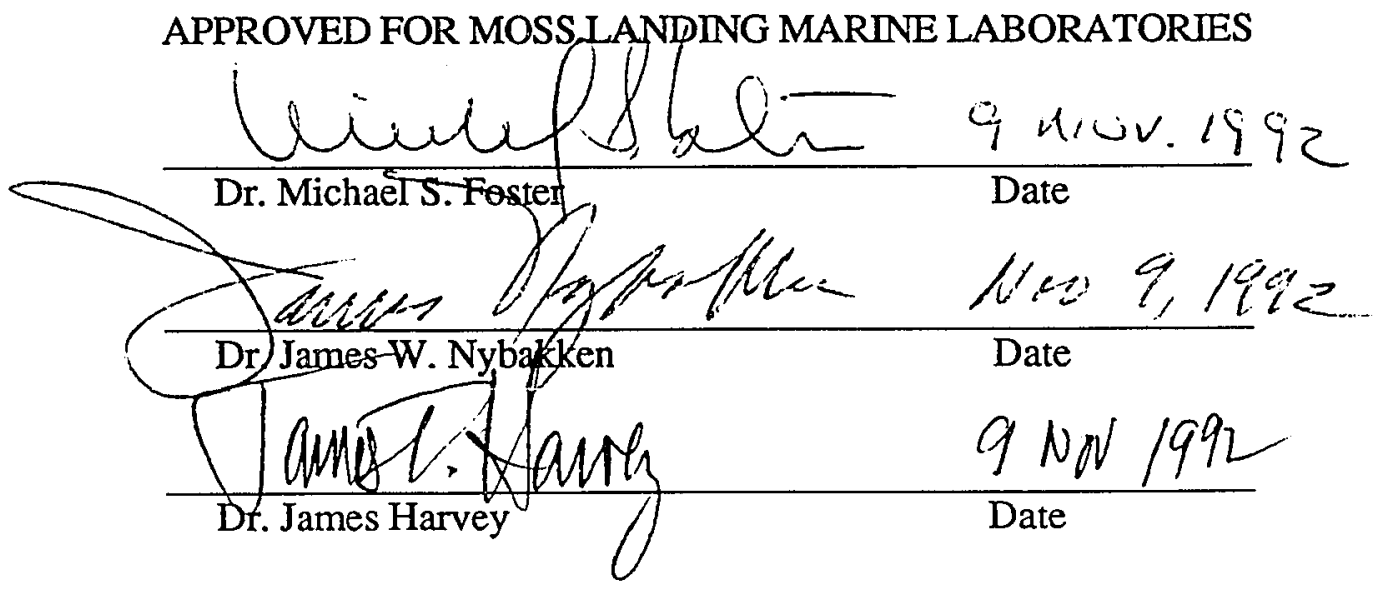

APPROVED FOR THE UNIVERSITY

Serena Mr. Stanford 


\section{UMI ABSTRACT \\ EFFECTS OF HERBIVOROUS GASTROPOD \\ SPECIES AND DENSITIES ON EARLY ALGAL SUCCESSION IN THE HIGH INTERTIDAL ZONE}

by John A. Tarpley

Field manipulations, laboratory feeding experiments, and comparisons with a larger, multi-site study of intertidal succession were used to determine the effects of herbivorous gastropod species and densities on early algal succession in the high rocky intertidal zone at two sites in central California. The grazers studied were: "Collisella" scabra and Lottia digitalis, and Tegula funebralis and Littorina scutulata/plena.

The effects of grazer species were limited and did not strongly regulate early succession, but increasing grazer densities decreased algal abundance. To estimate the cumulative impact of grazers on the algal community, a system of "mean grazer units" was developed from algal consumption rates.

The common grazers used in this study were able to alter algal abundance and species composition on high intertidal shores. By consuming small ephemeral and perennial algae, various densities of grazers can either hasten or prolong early algal succession. Results also suggest that the magnitude of such complex interactions are site dependent, directiy affected by local site characteristics.

Major Adviser: Dr. Michael S. Foster 


\section{ACKNOWLEDGMENTS}

This research would not have been possible without the help and support of many people. I would like to take this opportunity to thank them here. To the faculty, staff, and students of Moss Landing Marine Laboratories who provided assistance throughout my educational experience and were always there when the tides were low. To Hopkins Marine Station for valuable laboratory space. To my thesis committee members for their input and encouragement: Dr. James Nybakken, Dr. James Harvey, and especially Dr. Michael Foster, who kept me on course, provided inspiration, and made me a better scientist. To my parents, Mr. and Mrs. John J. Tarpley, Jr., for their never ending support. And finally, to Susan Dearn, who was patient and encouraging through the cold rainy days of sampling and the seemingly never ending evenings of number crunching and writing, I am deeply grateful.

This research was funded in part by the Minerals Management Service, a grant from the Earl and Ethel Meyers Oceanographic Trust, and generous support from the people and resources at Kinnetic Laboratories, Inc. 


\section{TABLE OF CONTENTS}

LIST OF TABLES

LIST OF FIGURES

$\underline{\text { Page }}$

vii

ix

$\begin{array}{ll}\text { ABSTRACT } & 1\end{array}$

INTRODUCTION 3

MATERIALS AND METHODS 6

Field Experiments 6

Pescadero Point Treatments $\quad 7$

Bolinas Point Treatments $\quad 8$

Sampling $\quad 9$

Laboratory Experiments 10

Macroalgal Grazing Experiments 11

Microalgal Grazing Experiments 13

Multi-site Intertidal Survey 16

$\begin{array}{ll}\text { RESULTS } & 19\end{array}$

Field Experiments 19

Observations of Algal Succession 19

Caging Effects 20

Grazer Effects on Single Algal Species $\quad 20$

Grazer Density Effects 20

Grazer Species Effects 21

Grazer Effects on Total Algal Cover 22

Grazer Density Effects 22

Grazer Species Effects 23

Grazer Effects on Species Richness 24 


\section{TABLE OF CONTENTS (Continued)}

Laboratory Experiments

$\begin{array}{ll}\text { Multi-site Intertidal Survey } & 27\end{array}$

$\begin{array}{ll}\text { DISCUSSION } & 32\end{array}$

Grazer Density Effects $\quad 32$

Grazer Species Effects $\quad 36$

Algal "Preferences" and Consumption Rates of Grazers 39

LITERATURE CITED 43

$\begin{array}{ll}\text { APPENDIX } 1 & 72\end{array}$

Algal Species Lists at Pescadero Point and Bolinas Point

APPENDIX 2

Algal Cover and Rock Space Results in Each Treatment 7 32 at Pescadero Point and Bolinas Point

Grazer Density Results of the Multi-site Study 


\section{LIST OF TABLES}

Table

Page

1 Grazer Species and Densities Used at Each Study Site

2 Significant Results of Analyses of Variance on the Effects of Grazer Density on a Single Algal Species at Both Sites and on Each of the Four Sampling Dates Analyzed.

3 Significant Results of Analyses of Variance on the Effects of Grazer Species on a Single Algal Species at Both Sites and on Each of the Four Sampling Dates Analyzed.

4 Mean Total Algal Cover for Each Treatment at Each Site Over All Sampling Times. Effects of Grazer Density and Grazer Species on Total Algal Cover at Both Sites and on Each of the Four Sampling Dates Analyzed.

6 Mean Number of Algal Species per Plot for Each Treatment at Each Site Over All Sampling Times.

7 Two-Factor Analyses of Variance on the Effects of Grazer Species and Density on Algal Species Richness.

8 Two-Factor Analyses of Variance of Macroalgal Feeding Experiments.

9 Results of SNK Multiple Comparison Tests on Each Grazer From the Macroalgal Feeding Experiments. Experiments 


\section{LIST OF TABLES (Continued)}

Table

Page

11 Mean Grazer Densities, Mean Percent Cover of the

Most Abundant Ephemeral Algae, and Mean Total Ephemeral Cover Per Plot at All Locations of the Multi-site Study.

12 Results of Pearson's Correlation Analysis of All Six

Multi-site Study Sites Combined. 


\section{LIST OF FIGURES}

Figure

Page

1 Location of Study Sites. 60

2 Diagrams of Treatment Manipulation Barriers. 61

3 Diagram of Laboratory Apparatus Used for Macro- 62 and Microalgal Feeding Experiments.

4 Early Algal Succession at Pescadero Point as Shown 63 in the Control Treatment.

$5 \quad$ Early Algal Succession at Bolinas Point as Shown in 64 the Control and Cage Control Treatments.

6 Mean Cover of Each Algal Taxon and Bare Rock Space in Each Grazer-density Treatment at Pescadero Point on Each Sampling Date.

$7 \quad$ Mean Cover of Each Algal Taxon and Bare Rock Space in Each Grazer-density Treatment at Bolinas Point on Each Sampling Date.

8 Mean Change in Macroalgal Wet Weight (grams) Over the Four-day Experiment in all Control and Grazer Treatments for Both Ulva spp.and Porphyra spp.

9 Mean Microalgal Consumption Rates of Each of the Four Grazers Over the Four-day Experiment.

10 Mean Total Ephemeral Cover and Mean Grazer Density Fluctuations Over Time at Pescadero Rocks. in Spring- and Fall-Cleared Treatments of the Multisite Study. 


\section{LIST OF FIGURES (Continued)}

Figure

Page

11 Mean Total Ephemeral Cover and Mean Grazer

Density Fluctuations Over Time at Bolinas Point in Spring- and Fall-Cleared Treatments of the Multisite Study.

12 Mean Total Ephemeral Cover and Mean Grazer Density Fluctuations Over Time With All Six Multisite Study Sites Combined. 


\begin{abstract}
Density, species composition, and selective grazing of herbivores may substantially alter the structure of algal assemblages via effects on early successional algae such as diatoms, blue-greens, and filamentous and foliose ephemerals. In this study, field manipulations, laboratory feeding experiments, and comparisons with a larger, multi-site study of intertidal succession were used to determine the effects of grazer species and density on early algal succession in the high rocky intertidal zone of two sites in central California. Four grazer species were chosen based on their frequency of occurrence and abundance throughout the study areas: the limpets, "Collisella" scabra and Lottia digitalis, and the snails, Tegula funebralis and Littorina scutulata/plena.

Grazer species had few effects on early algal succession, and did not strongly regulate primary succession or early algal assemblage structure. All grazers examined were generalist, opportunistic feeders that consumed ephemeral algae and the juvenile stages of perennials. All species of grazers consumed microalgae (plants with thalii $<1 \mathrm{~cm}$ iong) but onily Teguia and Littorina ate macroalgae. As a result of this consumption, all grazers slightly altered algal species composition and reduced total algal cover.

Grazer density had a much greater effect on algal succession than grazer species. As density of each species increased, algal cover decreased. This negative correlation was observed in all experiments and among all grazers throughout the experiments. Treatments with average and high densities of grazers had significantly less total algal cover than low-density or no-grazer treatments during the sampling period. High-density plots were nearly
\end{abstract}


devoid of ephemerals and most upright perennial algae regardless of the successional age of the plots. Algal species richness also decreased as grazer density increased, but the effect was not statistically significant.

Based on feeding experiments, a system of grazer equivalents, or "mean grazer units" was developed to estimate algal consumption in completely disturbed areas. Grazer units were derived from the mean consumption rates of microalgae and macroalgae for each grazer species. Because Tegula consistently consumed the most algae and was the most effective grazer in all experiments, it was chosen to equal one mean grazer unit (mgu). For microalgae: 1 Tegula equaled 2.4 Lottia (1 Lottia $=0.42 \mathrm{mgu}$ ), 3.7 "Collisella" (1 "Collisella" = $0.27 \mathrm{mgu})$, or 14.2 Littorina $(1$ Littorina $=0.07$ $\mathrm{mgu}$ ). For macroalgae, only Tegula and Littorina mgu values were calculated for grazing on Ulva lobata. They were: one Tegula equaled one mgu and one Tegula equals approximately 18 Littorina $(1$ Littorina $=0.05 \mathrm{mgu})$.

Overall, the common herbivorous gastropods used in this study were able to alter algal abundance and species composition on high intertidal shores. By consuming small ephemerals and, in some cases, juvenile perennial algae, various densities of grazers can either hasten or prolong early algal succession. Results also suggest that the magnitude of such complex interactions are site dependent, directly affected by local site characteristics. Thus, the effects of grazers on early algal succession must be addressed on a site-by-site basis. 


\section{INTRODUCTION}

Revegetation of bare substratum following a disturbance has been referred to as "primary succession" (Clements 1916). The rate of this succession and the processes that affect the rate can be as varied and unpredictable as the factors that produced the disturbance. In marine intertidal ecosystems, physical factors such as substratum type, tidal height, desiccation, temperature, sand scour, wave exposure, and season; and biological factors such as availability of spores and larvae, competition, and predation (or herbivory in the case of plants), can all affect succession and alter the resulting community structure (Ricketts et al. 1985).

In intertidal algal communities, one current paradigm of succession common to all plant communities suggests that following a disturbance the typically short-lived "weedy" ephemeral species "invade" and then are succeeded by longer-lived perennial species. Biological and physical factors may affect the rate of succession or recovery, but the community will eventually be similar to what it was before the perturbation unless another disturbance occurs.

Of the many potentially influential factors, the effects of herbivores have been of primary interest in nearshore marine reef communities. Plantherbivore interactions, especially grazing, dramatically affect algal community structure in many marine systems (see reviews by Branch 1981; Lubchenco and Gaines 1981; Hawkins and Hartnoll 1983). Sousa $(1979,1984)$ examined plant-herbivore interactions and the effects of grazers on mid-intertidal algal communities during succession, and found that grazers did have effects 
although they were not long-lasting. Lubchenco and Menge (1978) found that littorines in the low rocky intertidal zone enhanced the reestablishment of the perennial Chondrus crispus by removing ephemeral algae and epiphytes. In another study, the combined actions of herbivory and algal competition kept fucoids from reestablishing in intertidal pools (Lubchenco 1982). In northern California, littorines were effective grazers where algae colonization on abundant barnacle cover, and limpets were important where barnacles were scarce (Geller 1991).

Many researchers have suggested that herbivores, especially gastropods, can affect the disturbance and abundance of their algal foods (e.g., Southward 1964; Cubit 1984; Lubchenco 1978, 1982; Underwood 1979; Underwood and Jernakoff 1981; Duggins and Dethier 1985; Petraitis 1987; Watson and Norton 1987). A number of researchers that have studied grazing have examined changes in algal zonation (e.g, Castenholz 1961; Haven 1973; Anderson 1987), temporal fluctuations in algal or grazer abundance (e.g., Underwood and Jernakoff 1981; Cubit 1984), the algal foods of grazers (e.g., Foster 1964; Eaton 1968; Kitting 1979, 1980; Nicotri 1980; Watson and Norton 1985, 1987), and herbivore behaviors (e.g., Eaton 1968; Nicotri 1977; Watson and Norton 1987). Some studies suggest that preferential feeding by particular species of grazers can change abundance and/or composition of algal species characteristic of early succession, such as diatoms, filamentous red and green algae, and various foliose ephemerals (Lubchenco 1978, 1982; Sousa 1979, 1984; Petraitis 1983). These studies and Petraitis (1987) and Farrell (1988) indicated that it was possible for grazers to regulate succession by maintaining or excluding particular algae. 
Despite strong evidence that herbivores have the potential to influence algal communities, direct effects of grazing during early succession have not been thoroughly investigated. It is during early succession that herbivores in temperate intertidal zones, especially in the high intertidal zone, may have the greatest impact on the algal community (Foster 1992). My primary objective was to determine the specific effects of different species and densities of herbivores on early algal succession in the high rocky intertidal Endocladia/Mastocarpus assemblage of central California. Effects of grazer species and density on individual algal species, total algal cover, and algal species richness were examined during early algal succession following a complete disturbance. The second objective was to determine consumption rates of each grazer species on select macro-and microalgae to better evaluate their relative effects on algal succession. The final objective was to determine if grazing effects were similar at other locations to expand the geographical scope of this study. To do this, data from a larger, multi-site study of succession were examined for grazer-algal relationships based on site-specific differences in grazer density, algal abundance, and species composition of early successional, ephemeral algae.

Four of the most abundant and widely distributed high intertidal grazers in central California were examined. They were the limpets, Lottia digitalis and "Collisella".scabra, and the snails, Littorina scutulata and Tegula funebralis (Morris et al1980). These herbivores were chosen because of their high abundance in the field, and because evidence from other studies indicated that they had the potential to affect early algal succession. 


\section{MATERIALS AND METHODS}

\section{Field Fxperiments}

Field experiments were done at Pescadero Point $\left(36^{\circ} 33^{\prime} \mathrm{N}, 121^{\circ} 57 \mathrm{~W}\right)$ on the north side of Carmel Bay, and at Bolinas Point $\left(37^{\circ} 54^{\prime} \mathrm{N}, 122^{\circ} 43^{\prime} \mathrm{W}\right)$ on Duxbury Reef near Bolinas, California (Figure 1). The latitudinal distance between the sites was $1^{\circ} 21^{\prime}$ (approximately $129 \mathrm{~km}$ ). Study sites were selected based on the plant/herbivore assemblage present, available size of study area, and restricted public access. Both study sites were approximately 1.3 to $2.0 \mathrm{~m}$ above Mean Lower Low Water in the high intertidal zone. At these sites, this zone is dominated by two species of algae, Endociadia muricata and Mastocarpus papillatus. Pescadero Point is composed of granite benches and large boulders exposed to moderate to heavy surf from the south and southwest. Bolinas Point is a large, broad, and relatively flat mudstone reef which is swept by waves and swells from the northwest to the south at high tide.

In February and March 1989, complete clearings were made at Pescadero Point and Bolinas Point, respectively. Random plots, $25 \times 25 \mathrm{~cm}$ $\left(0.0625 \mathrm{~m}^{2}\right)$, were cleared by chiseling off all macroalgae and invertebrates and scraping the plot with a wire brush. The area within each plot was then burned with a hand-held propane torch until the rock surface was dry and hot. Scraping and burning was then repeated a second time. This technique assured that all plots were sterile and that each plot had a common starting point for succession. 
A. Pescadero Point Treatments

Treatments at Pescadero Point included manipulations to examine effects of grazing from low, average, and high densities of "Collisella" scabra (hereafter "Collisella"), Lottia digitalis (hereafter Lottia), and Littorina scutulata/plena (hereafter Littorina) on early algal succession (Table 1). Natural grazer densities were determined from surveys of grazer counts in the Endocladia/ Mastocarpus zone at each site. Low and high densities represented the minimum and maximum riatural densities found for each grazer. "Collisella" and Lottia used in these studies had shell lengths between 1 and $2 \mathrm{~cm}$. Littorina treatments included a random selection of individuals of varying sizes found at the study site. A control treatment that excluded all grazers was also included to determine algal succession unaffected by grazers. A more typical control allowing access by all grazers was not used because interest was in the effects of a particular grazer species and densities on algal succession, not their combined effects. Each treatment was replicated four times for a total of 40 cleared plots.

Barriers to maintain treatment densities of the two limpet species, littorine, and control treatments consisted of a $4-\mathrm{cm}$ wide band of rubberbacked astroturf surrounded by a $4-$ to $5-\mathrm{cm}$ band of the sticky compound Tree Tanglefoot $($ Pest Barrier (Figure 2A). Astroturf was epoxied to the substratum using Z-Spar @ Splash-zone Epoxy Compound. This low-lying barrier restricted grazer movement into and out of plots. 


\section{B. Bolinas Point Treatments}

Bolinas Point was chosen to examine the effects of Tegula funebralis (hereafter Tegula ) grazing at low, average, and high densities because Tegula were abundant (Table 1). The effects of average densities of "Collisella" and Lottia were also examined. Grazer densities and controls were chosen in the same manner as at Pescadero Point with four replicates per treatment. Due to logistical constraints, low and high density treatments for both limpets were not examined. Littorina was not studied at this site because its density and movements could not be controlled. Wave action washed littorines uncontrollably across the relatively flat mudstone bench.

To maintain Tegula densities, a $25 \mathrm{~cm} \mathrm{X} 25 \mathrm{~cm}$ cage of stainless steel wire mesh $(1.27 \times 1.27 \mathrm{~cm} ; 0.5 \times 0.5 \mathrm{in})$ was epoxied to the substratum over the cleared plot (Figure 2B). The height of the cage was approximately $5 \mathrm{~cm}$ above the substratum, with a $10 \times 10 \mathrm{~cm}$ door on the top for access when sampling. Astroturf and Tree Tanglefoot surrounded the outer perimeter of the cage to prevent additional animals from entering and to maintain consistency of any cage effects among all plots. The limpet and control treatment barriers were identical to those used at Pescadero Point (Figure 2A). An additional control treatment was added at Bolinas Point to test for any effects due to the wire cages. These cage controls were constructed of stainless steel wire mesh and were surrounded by astroturf and Tree Tanglefoot barriers. They contained no grazers and two sides were open (Figure 2C). The cage control and control treatment were compared for effects due to shading, changes in water motion, or protection from predation provided by the cage. 


\section{Sampling}

Algal abundance and composition within each plot were sampled monthly for 16 months at Bolinas Point and 18 months at Pescadero Point. Sampling continued until ephemeral algae were replaced by perennials. A

point quadrat was used to estimate algal cover in the plots. It consisted of a 25 $\times 25 \mathrm{~cm}$ plexiglass plate with 100 evenly spaced holes and three adjustable legs, similar to but smaller than that described by Foster et al. (1991). To sample each plot, the point quadrat was placed 15 to $20 \mathrm{~cm}$ above the substratum and a $61 \mathrm{~cm}$ long brass pin was lowered through each of the 25 randomly chosen holes. For each hole, all layers of algae and/or abiotic substrata contacted were identified and recorded, so cover could exceed 100 percent. A new set of random holes was selected for each sampling date. The assortment and arrangement of holes were different for each sampling date, and the use of any single hole was not repeated for at least three months to maintain randomness and independence. Species that could not be identified in the field were collected for later identification.

Grazer densities and plot barrier conditions were checked and maintained during each sampling period, and commonly two or three times per month. In addition to point quadrat sampling all plots at each site were photographed and qualitative observations were made during each survey.

Trends in algal abundance were examined by plotting mean abundances through time for each treatment. Only those algal species that exceeded 10 percent cover at least once during the sampling period were included in these analyses. Because the plots were not independent with respect to time, the data were not analyzed with analysis of variance 
(ANOVA) using time as a factor. Instead, four discrete sampling dates $(4,8$, 12 , and 16 months after clearing) were chosen, based on peak algal abundances and on what appeared to be distinct successional assemblages at different times throughout the experiment. Algal abundance data from the four sampling periods were tested separately using ANOVA. I examined the effects of 1) grazer density on each algal species (e.g. the effects of low vs. average vs. high densities of Tegula on Mastocarpus papillatus, or low vs. average vs. high densities of "Collisella" on Ulva lobata) and 2) grazer species at each density on each algal species (e.g. the effects of average densities of Lottia vs."Collisella" vs. Littorina on Ulva lobata). These analyses indicated which species and which density had the greatest effect on algal succession. Similarly, grazer species and density effects on total algal cover and algal species richness also were tested using ANOVA. Homogeneity of variance for all data sets was analyzed using Cochran's test (Winer 1971) and arcsine transformed when necessary.

\section{Iaboratony Experiments}

Algal foods and consumption rates of the grazers were examined in two separate manipulative experiments. Microalgae, less than $1 \mathrm{~cm}$ in height, were used in the first experiments and macroalgae (generally $>10 \mathrm{~cm}$ ) were used in the second experiment. In both experiments, only ephemeral algal species were examined because they commonly dominate early succession. 


\section{A. Macroalgal Grazing Experiments}

Feeding experiments were done in the spring of 1990 at Hopkins Marine Station (HMS) in Pacific Grove, California. Macroalgae used were Ulva lobata and a combination of Porphyra lanceolata and Porphyra perforata This combination was necessary because these species grow in dense, mixed patches, and it is difficult to identify the species of young nonreproductive plants in the field. Both genera used are common in the high intertidal zone of central California (Abbott and Hollenberg 1976), and are opportunistic species that commonly invade disturbed areas (Sousa 1979; Foster et al. 1988). It is highly probable that they are often encountered by each of the grazers. Furthermore, the radula of the grazers in this study make it possible for them to graze and ingest these genera (Steneck and Watling 1982).

Although these studies are termed "laboratory experiments," the experimental conditions were designed to be representative of the natural intertidal environment. The experimental apparatus (Figure 3) was located outdoors near the intertidal zone of HMS, exposed to ambient temperature, humidity, and light. A computerized water timer regulated seawater flow that mimicked tidal cycles. The tidal sequence for the duration of each experiment was determined at the tidal height at which the organisms were collected (approximately $+1.5 \mathrm{~m} \mathrm{MLLW}$ ) and programmed into the timer. The timer and valve automatically turned the seawater flow on or off when the tide was either flooding or ebbing, respectively. A misting device $20 \mathrm{~cm}$ above each of the 24 clear plexiglass tanks $(25 \times 25 \times 20 \mathrm{~cm})$ sprayed seawater into each tank. During high tide, the tanks flooded to a depth of $1-2 \mathrm{~cm}$ submerging the grazers and the algae. All tanks were placed on a slight 
incline with small holes approximately $1 \mathrm{~cm}$ above the bottom, which served as a spillway during high tide. At low tide, the tanks drained nearly dry, so the algae and grazers were exposed to the air. To keep the grazers from climbing up and out of the tanks, a thin plastic screen was secured over the top of each tank. However, in most cases, grazers remained under the algae or on the bottom of the tank and rarely climbed the walls.

All experimental trials involved only one grazer species and one algal species in each chamber. All possible combinations of grazers and algae were examined. Treatment densities were ten "Collisella," ten Lottia, ten Tegula, and 100 Littorina, and were within the range of natural densities found in field surveys at the two field study sites (Table 1). Grazers were placed in 12 randomly chosen tanks with the algal species to be tested and the remaining 12 tanks served as no-grazer controls with algae alone. Algae and grazers for each experiment were collected near Pescadero Point, and grazers were starved for three days before the experiment. Algae were rinsed in seawater and cleaned of any epiphytes or epifauna, spun in a salad spinner at $300 \mathrm{rpm}$ for 15 seconds (approximately 75 revolutions) to remove excess water, and lightly blotted dry and weighed. Duration of all experiments was four days. After the experiment, algae were treated as above, weighed again, and changes in algal biomass were calculated. Grazers were returned to the collection site and new individuals collected for the next experiment.

Two-way analysis of variance and Student-Newman-Keuls multiple comparison tests were performed on data from each experiment. In each test, the effect of grazer presence (or absence, in the case of controls) was compared for both algal species (Ulva and Porphyra) to determine any significant 
changes in algal biomass. To properly analyze consumption, it was necessary to examine interaction significance to address the question of whether changes in algal biomass were caused by grazer consumption and/or natural physiological changes (Peterson and Renaud 1989). Results of these experiments were used to develop a system of equivalent grazing units for each grazer based on differences in the consumption of macroalgae for each grazer species.

\section{B. Microalgal Grazing Experiments}

The grazers in this study scrape microalgal foods from the substratum. Therefore, experiments were conducted to determine their preferences for and consumption rates of microalgae. Algae were grown in situ on $23 \times 23 \mathrm{~cm}$ settling plates made of $0.635 \mathrm{~cm}$ thick grey flat PVC. One surface of each plate was roughened with 40-grit sandpaper using a belt sander in two directions across the plate. Settling plates were placed in the high intertidal zone at HMS. After seven weeks, the plates were completely covered with a microalgal $(<1 \mathrm{~cm})$ turf of Urospora sp., Enteromorpha sp., Bangia sp., Blidingia sp., and diatoms.

Experiments were done in the summer of 1990, using the apparatus previously described for the macroalgal grazing experiments. Treatments included the four separate grazer species and two control treatments with no grazers. One control was allowed to run the duration of the experiment; the second set was analyzed before the experiment began.

Consumption of microalgal biomass was measured using chlorophyll analysis to detect changes in chlorophyll a. This technique was destructive; 
therefore, the ungrazed before-experiment algal treatment was used to estimate the algal biomass of all plates at the beginning of the experiment. When compared with the ungrazed after-experiment control treatment, an estimate of the natural change in algae during the experiment was obtained. Point quadrat sampling was also done on each plate at the beginning and the end of the experiment to estimate change in algal cover. All treatments were replicated four times.

Four settling plates were randomly selected for the before-experiment controls. Remaining plates were randomly placed in each treatment tank and the grazers added. Grazer treatment densities used were approximately equal to the average natural densities found at the field study sites (Table 1). Based on results from pilot studies with higher than average densities of grazers, it was suspected that some grazers could clear the plate of microalgae before the experiment ended. If this were to happen, consumption rates would have been underestimated. Therefore, to insure sufficient algae for grazing, grazer densities for these experiments were half of those used in the macroalgal grazing experiments. Densities were five per replicate for "Collisella," Lottia, and Tegula, and 50 per replicate for Littorina. The experiment continued for four days.

At the conclusion of the experiment, algal cover of each plate was sampled then the plates were transported to the lab in a dark iced cooler for chlorophyll a analysis.

Chlorophyll analysis was done using standard methods (Parsons et al. 1984). All algae were scraped from the plate into a known volume of seawater and thoroughly mixed. Three replicate aliquots of each plate 
mixture were removed and filtered. Chlorophyll was extracted using 90 percent acetone and allowed to stand overnight in a dark freezer $\left(-15^{\circ} \mathrm{C}\right)$. Absorbance spectra of chlorophyll pigments were measured at 664,647 , and $640 \mathrm{~nm}$. Values were corrected for dilution factors and the absorbance of other pigments. The mean of the ithree replicate aliquots was used as the chlorophyll concentration of each plate. Concentration was recorded as micrograms chlorophyll a per plate. Chlorophyll a was not standardized for a defined unit of algal biomass because each plate contained a number of algal species. However, because all plates had a similar algal composition, a single concentration was determined for the whole plate "community." Consumption rates of chlorophyll a were then compared among grazers, based upon the relative abundance of all microalgae in general.

To analyze the microalgal grazing data, the change in algal biomass of no-grazer controls from beginning to end of the experiment was calculated with a $t$-test. No significant difference was found so replicates were pooled and a mean algal biomass was calculated, representing multiple algal species on a single plate. This mean was then subtracted from each grazer treatment replicate. These data were converted to micrograms of chlorophyll a consumed per individual grazer and consumption differences between species of grazers were examined using a single-factor ANOVA. From these experiments, a system of equivalent grazing units for each grazer was determined based on consumption rates of microalgae by each grazer species. Values were derived from the mean change in chlorophyll a consumed per individual per day. 
Algal preferences of each grazer were examined using ANOVA to test for differences in changes in algal cover or bare space. Because algae on the plates were nearly impossible to identify to species, three basic algal categories (green filaments, red filaments, and diatoms) and bare space were used for statistical analyses.

\section{Mulli-site Intertidal Survey}

To expand the scope of this study over a larger geographic area and gain a greater understanding of plant-herbivore interactions during succession in the Endocladia/Mastocarpus assemblage, I used data from a larger, concurrent study in the same region [Kinnetic Laboratories, Inc. (KLI) 1992]. In this experiment six study sites were spread over a $4^{\circ} 23^{\prime}$ latitudinal range throughout central and northern California. Sites ranged from near Ft. Bragg south to San Luis Obispo. Two sites, Bolinas and Pescadero Rocks, were within 200 meters of my sites at Bolinas Point and Pescadero Point, respectively.

To examine seasonal differences and successional patterns, disturbances were created in the Endocladia/Mastocarpus assemblage at each site by clearing and burning the substratum in spring and fall. Three replicate plots $(1 \times 2 \mathrm{~m})$ for each seasonal treatment and three undisturbed control plots were quantitatively sampled before clearing, three months following each clearing date, and semi-annually thereafter for six years. Sampling was done using three randomly chosen $25 \times 25 \mathrm{~cm}$ quadrats within each plot. Point 
quadrats were used to estimate algal cover, and direct counts were used to estimate motile invertebrate abundance (for details, see KLI 1992).

Data from this study were used to determine natural variation in the density of grazers, ephemeral algal cover, and species-specific grazer/alga interactions at each study site, particularly Pescadero Rocks and Bolinas. Data on grazer densities and percent cover of ephemeral algal species during the first 24 months after clearing were used. Mean densities for each grazer and mean cover of ephemeral algae were calculated for each season at each site. Density values were the mean of three plots, determined from the sum of counts in the three quadrats per plot (total area $=0.1875 \mathrm{~m}^{2}$ ). Cover values were the mean of three plots, with each plot value determined from the mean of three quadrats. Data from each site were plotted and qualitatively examined for possible relationships between grazers and ephemeral algal cover. Comparisons also were made between seasons and among sites.

The multi-site data also were used in a series of Pearson's correlation tests in an attempt to generalize the effects of grazers on early algal succession over a larger geographic scale. Comparisons of these results could then be made to the present study. The following grazers and ephemeral algae were selected and tested: 
Total Ephemeral Cover = Mean ephemeral cover observed in each plot among sample periods between initial disturbance and recovery within 24 months. Species of ephemeral algae included for calculation of this variable were:

Filamentous diatoms

Enteromorpha compressa

E. intestinalis

E. linza

Enteromorpha $\mathrm{sp}(\mathrm{p})$.

Urospora wormskioldii

Urospora penicilliformis

Green filaments
Ulva californica

U. Jobata

Ulva sp(p).

Porphyra lanceolata

P. perforata

Porphyra sp(p).

Urospora doliifera

Green blades

Green algae that grow on rocks (G.A.T.G.O.R.)

Grazer Density = Mean density of all combined grazers in each plot among sample periods through the time of first plot recovery. The individual grazer species densities were weighted according to mean grazer units (for details, see Methods and Discussion) to reflect differences in consumption rates.

In these correlations, the value for each variable was the mean of combined replicate plots at each site. Analyses were performed for springand fall-cleared treatments separately $(n=6)$ and combined $(n=12)$. 


\section{RESULTS}

\section{Field Experiments}

A. Observations of Algal Succession

Algal growth in the grazer-free control plots was visible within weeks after the initial clearing. The first identifiable alga to grow at Pescadero Point was Urospora spp., which reached maximum mean abundance of 49 percent in the control treatment in about two months (Figure 4). Porphyra spp. and diatoms also increased during this period. After five to six months (in July and August), Porphyra spp. peaked between 50 and 95 percent cover in some treatments, then decreased to lows of 5 percent to 20 percent in January and February. Mean diatom cover peaked (after eight months) in October as Ulva lobata, Blidingia minima, and GATGOR (acronym for "green algae that grow on rocks," consisting of a mixture of minute blades and filaments of mainly Ulva spp., Blidingia spp., and Enteromorpha spp.) settled and increased in cover through winter. Approximately one year after clearing mean cover of $U$. lobata and B. minima peaked at 58 percent and 24 percent, respectively, then decreased in the spring and with increasing Porphyra spp. cover (Figure 4). Throughout the second summer, fucales such as Fucus gardneri and Pelvetia fastigiata began to occur in the plots. Among all treatments, 26 algal taxa occurred at this site throughout the study (Appendix 1).

At Bolinas Point, only one alga, Ralfsia spp., and two barnacle species, Balanus glandula and Chthamalus dalliwere initially present in all plots two months after clearing (Figure 5). Ephemeral algal species were not abundant 
at this site. Porphyra spp., Ulva spp., and filamentous reds occurred occasionally in many plots throughout the experiment but coverage of these taxa were never greater than 10 percent. Total algal cover remained low for seven to ten months after clearing until late summer and fall when perennial species such as Mastocarpus papillatus, Fucus gardneri, and Ralfsia spp. increased in abundance, dominating the plots along with Cryptosiphonia woodii and Analipus japonjcus. At Bolinas Point, 27 algal taxa occurred (Appendix 1).

\section{B. Caging Effects}

The only significant difference (based on ANOVA and subsequent multiple comparison tests, Table 2) between control and cage control treatments at Bolinas Point occurred after eight months when Fucus gardneri was more abundant in the control treatment. Overall, based on ANOVAs for each algal species during any sampling period, the cage had no major effect. This can be seen qualitatively in Figure 5.

\section{Grazer Effects on Single Algal Species}

1. Grazer Density Effects. Qualitative comparisons among densities for each grazer indicate a trend of relative decreases in algal cover and increases in bare rock with increasing grazer density. For each grazer species, cover of individual algal species (Figure 6; Appendix 2) also generally decreased with increasing grazer density.

At Pescadero Point statistically significant effects of grazing on an individual algal species were found in the low- and high-density Littorina 
treatments, where diatom cover was reduced more than in the averagedensity treatment after four months (Figure 6A, Table 2). No significant differences in single algal species were detected among density treatments during the eight- and 12-month sampling periods (Figures $6 \mathrm{~B}$ and $6 \mathrm{C}$ ). However, all densities of "Collisella," and high and low densities of Littorina significantly reduced Porphyra spp. cover after 16 months (Figure 6D, Table 2). Lottia had no significant effects on individual algal species at any density.

At Bolinas Point, Tegula significantly reduced several perennial species throughout the entire experiment. After eight months, high-densities of Tegula significantly reduced Mastocarpus papillatus cover when compared to low- and average-density treatments (Figure 7B, Table 2). Cover of Fucus gardneri also was significantly lower in all Tegula density treatments than in the control treatment (Figure 7B, Table 2). One year after clearing, high densities of Tegula continued to maintain reduced coverage of $M$. papillatus (Figure 7C, Table 2). Fucus gardneri, Cyptosiphonia woodii, and Endocladia muricata abundances were also reduced in these plots. Even after 16 months, average- and high-density Tegula treatments had significantly less $M$. papillatus than either of the control treatments. During the first eight months, average-density treatments were equivalent to the no-grazer controls, having no significant effect on any single algal species (Figure 7D, Table 2).

2. Grazer Species Effects. Analyses of grazer species effects were done using the same numerical data as with grazer density analyses, but have been configured differently to address the second hypothesis. Here, the interest is 
whether or not different species of grazers at similar densities have unique effects on algal cover.

At Pescadero Point, plots with average densities of Littorina had more diatoms than "Collisella," Lottia, or control treatments after four months (Figure 6A, Table 3). However, by 16 months the effects on Porphyra spp. cover were significantly decreased by all species in low- and high-density treatments (Figure 6D, Table 3).

At Bolinas Point, Tegula, "Collisella," and the control treatments had significantly less Fucus gardneri than Lottia throughout the entire duration of the experiment except at eight months (Figure 7, Table 3). No other significant species-specific grazer effects on any single algal species were found at Bolinas Point throughout the experiment.

Overall, few effects of either grazer density or grazer species on individual algal species were observed. Porphyra spp. at Pescadero Point and Mastocarpus papillatus and Fucus gardneri at Bolinas Point were most affected. After one year, all grazer treatments at Pescadero Point had less cover of ephemeral algae and more bare space than the control. None of the grazers consistently affected a single algal species or group of species, but reductions in total algal cover among all grazer treatments were observed.

\section{Grazer Effects on Total Algal Cover}

1. Grazer Density Effects. Despite finding very few density-dependent or species-specific grazer effects on any single algal species, there were several differences in the total algal cover present among density treatments (Table 4). At Pescadero Point, average- and high-density treatments of "Collisella" had 
significantly decreased the total algal cover more than the low-density and control treatments after eight months (Tables 4 and 5). The high-density treatments of Lottia and Littorina also had a mean algal cover less than other density treatments, although the differences were not statistically significant. All Lottia and Littorina treatments had over 100 percent total algal cover (Table 4). After 12 months, algal cover in high-density "Collisella" treatments was still significantly less than in low-density and control treatments. Highdensity Lottia and Littorina treatments again had the lowest algal cover although differences among treatments were not significant. After 16 months at Pescadero Point, only average- and high-density "Collisella" treatments had a significant decrease in total algal cover compared to the control (Table 5). No significant differences in total algal cover among densities of Lottia were noted throughout the experiment. Overall, the high-density treatments typically had less algal cover, more bare space, and fewer algal species than low, average, or control treatments (Table 4).

At Bolinas Point, Tegula density effects were only tested against the two control treatments due to the nature of the experimental design. Only after a period of one year were significant differences in total algal cover apparent (Table 4). After 12 and 16 months, there was significantly less total algal cover and more bare space in the high-density treatment than in either of the low, average, or control treatments (Table 5). Total algal cover in the two control treatments were never significantly different.

2. Grazer Species Effects. There were few significant species-specific grazer effects on total algal cover (Table 4), and only at Pescadero Point were these effects significant (Table 5). After eight months, average and high 
densities of "Collisella" and Littorina had significantly reduced algal cover more than the Lottia or control treatments (Table 5). No differences were detected among grazer species in low-density treatments at any sampling period. After 12- and 16-months, significant differences in total algal cover between species were not detected although trends remained the same as at eight months (Table 5). Mean algal cover in "Collisella" treatments of all densities was less than that of Littorina, Lottia and control treatments.

At Bolinas Point, there were no statistically significant effects of grazer species on total algal cover at average densities. However, Tegula and "Collisella" often had the lowest total algal cover among all grazer and control treatments (Table 5). The control and cage control treatments were not significantly different.

\section{E. Grazer Effects on Species Richness}

Few significant differences in algal species richness among treatments were detected (Tables 6 and 7). Grazer density had no effect on species richness during the experiment (Table 7). Grazer species effects on the number of algal species present were limited. At Pescadero Point, significant differences were present only after 16 months when all grazer treatments had significantly fewer algal species than the control treatment although there were no differences among species (Table 7). Algal species absent in all grazer treatments but present in the controls were Blidingia minima, Endocladia muricata, Fucus gardneri, and Pelvetia fastigiata. The presence of perennials only in control treatments suggests that the grazers may delay succession. At 
Bolinas Point, Tegula treatments had consistently fewer algal species than any other grazer or control treatment (Table 6).

\section{Laboratory Experiments}

A. Macroalgal Grazing Experiments

Results of all macroalgal grazing experiments are reported as changes in algal wet weight through time ( $\mathrm{mg} /$ individual/day). This indicates the amount of an alga consumed by a grazer and/or physiological change in the alga. A more negative or less positive algal biomass for the grazer treatment than for the no-grazer control indicates consumption. For the purpose of this study, increased consumption rates are interpreted as "preferential" feeding even though multiple algal foods were not offered to each grazer as in other studies.

The experimental apparatus functioned well and grazing appeared normal. Grazer densities were maintained within the tanks and individuals showed no indications of ill-health at the end of any experiment. Any artifacts due to the apparatus were minimal and were not believed to have altered the results.

The interaction term of the two-factor ANOVA on consumption and algal preference for Tegula was not significant (Table 8), indicating that although Tegula consumed both species, it had no statistically significant "preference" for either species. However, significance was observed in the grazer and algae factors. When the treatment means were plotted (Figure 8), an apparent difference was present among treatments. A multiple 
comparison test (Table 9) indicated that both algal treatments with Tegula were significantly different from those without, suggesting that both algal species were consumed. Based on the changes in wet weight (Figure 8A), Tegula ate more Ulva lobata than Porphyra spp. In these experiments, an individual Tegula could consume an average of $43 \mathrm{mg}$ (wet wt.) of Ulva per day or an average of $29 \mathrm{mg}$ of Porphyra per day.

A significant interaction between Littorina and the algae was observed (Table 8). Data from grazer treatments for each alga (Figure 8B, Table 9) indicated that significantly more Ulva was consumed ( 2.3 $\mathrm{mg} /$ individual/day) than Porphyra spp., suggesting that Ulva lobata was "preferred." When compared to Tegula, individual littorines consumed about 18 times less Ulva.

Data from the Littorina/Porphyra experiment, as well as the Lottia/Porphyra experiment, yielded unexpected results. In both cases, the presence of the grazer appeared to slightly increase the growth (or possibly reduce senescence) of Porphyra (Figures $8 \mathrm{~B}$ and $8 \mathrm{C}$ ). This resulted in only small differences between the grazer and no-grazer treatments (Table 9).

There were no interactions between Lottia and the algae; therefore, there were no significant grazing effects on either macroalgal species (Tables 8 and 9). There were also no significant differences among "Collisella" treatments (Table 9), indicating that there were no grazing effects and no macroalgal preferences. Algal wet weights decreased slightly during "Collisella" treatments but were very similar to each other (Figure 8D, Table 9). 


\section{B. Microalgal Grazing Experiments}

Microalgae available for consumption included Urospora spp., Enteromorpha spp., Blidingia minima, Bangia fusco-purpurea, and diatoms. Chlorophyll $a$ analyses indicated that individual consumption rates of the four grazer species were not significantly different over the four-day experiment due to high variability among replicate limpet treatments (Figure 9). Nevertheless, Tegula consumed the most per individual, and Littorina consumed the least (Figure 9). A positive relationship between mean consumption rate and body size was also apparent.

Tegula was the only grazer that indicated any significant microalgal food preference. It preferred green filamentous algae to diatoms, and significantly increased the amount of bare space on the settling plate (Table 10). Tegula consumed $4.0 \pm 1.3$ percent of the area of green filaments during the experiment, and bare space increased $24.1 \pm 5.0$ percent. "Collisella" also "thinned" the algae on the plate, significantly increasing bare space (Table 10). No other species showed statistically significant feeding preferences.

\section{Mulii-site Intertidal Survey}

"Collisella," Lottia, Tegula, and Littorina densities and total ephemeral cover during the first 24 months of succession at each of the six study sites indicated a wide range of variability among sites at any particular sampling time, and between seasons (Table 11, Appendix 3). Because of the complexity and multitude of possible comparisons indirectly related to the present study, plant-herbivore interactions were examined only at those sites near those in 
this study, Pescadero Rocks and Bolinas. Examination of grazer density and ephemeral algal cover fluctuations in both season and control treatments identified some of these interactions.

At Pescadero Rocks, ephemeral algal cover in the undisturbed control plats was very low (less than 10 percent) throughout the sampling period and consequently, has not been reported in the figures. Algal cover in both spring- and fall-cleared plots showed a dramatic increase to more than 100 percent within the first six months, then slowly decreased to less than 20 percent 18 to 24 months after clearing (Figure 10A). Ulva spp. and Enteromorpha spp. were the major ephemeral algae.

In spring-cleared plots, "Collisella" densities followed the algal curve lagging three to six months behind. The peak density $(199.00 \pm 43.22 / 0.1875$ $\mathrm{m}^{2}$ ) occurred in fall 1986, 18 months after clearing, and then dramatically decreased over the next six months (Figure 10B). Densities in fall-cleared plots remained near zero for the first year, then gradually increased the second year. An apparent interaction was present between "Collisella" and ephemeral cover, during both seasons algal cover decreased as grazer density increased. When algal cover dropped below 20 percent, grazer density also decreased.

Lottia densities in spring-cleared plots increased gradually during the first year, then rapidly during the second year to an average of $152.33 \pm 56.28$ per $0.1875 \mathrm{~m}^{2}$ (Figure 10C). Density did not appear to be correlated with ephemeral algal cover, which increased sharply in the first three months, then gradually declined over the following year (Figure 10A). Density in fallcleared plots gradually increased and coincident with increases in ephemeral 
algal abundance, but densities were never as high as of those in the springcleared treatment.

Tegula was almost completely absent from Pescadero Rocks for the duration of the sampling period and its abundance was not correlated with ephemeral cover. Littorina densities however, were extremely variable and either were not related to algal abundance or were negatively associated with it (Figure $100 \mathrm{D})$.

Grazer densities at Bolinas Point were unrelated to ephemeral algal cover, and cover never exceeded five percent (Figure 11A). Grazer densities were different from those at Pescadero Rocks. Maximum "Collisella" density was seven animals per plot in any treatment (Figure 11B). Densities of Lottia $(<11 /$ plot) remained relatively stable after clearing throughout the sampling period (Figure 11C). Tegula was abundant at Bolinas in all treatments. After an initial decline in both cleared plots, Tegula densities increased steadily until they peaked in the spring of 1987 at 26 to 29 individuals per plot (Figure 11D). Littorina densities in all treatments increased in the summer then gradually decreased through the winter (Figure 11E). Densities in spring- and fall-cleared plots were approximately 175 per plot after the first three months and then dramatically increased two to four fold during the next three months. After six months, Littorina densities declined.

Because this multi-site study was not designed to determine if speciesspecific interactions existed at each of the six study sites, effects of grazer species on algal abundances and algal succession could not be assessed. Instead, grazer densities for the four species examined in the present study and total ephemeral algal cover from the six study sites were compared. 
These data were combined and the means were plotted over the first 24 months of succession (Figure 12). From qualitative analyses of these graphs, some trends emerged. Total ephemeral cover in both spring- and fall-cleared plots increased rapidly in the first six months after clearing and then gradually decreased (Figure 12A). In general, the amount of ephemeral algae appeared to be negatively associated with grazer abundance.

With all sites combined, densities of both limpet species, "Collisella" and Lottia, were negatively associated with algal cover. "Collisella" abundance lagged slightly behind algal cover in both the spring- and fallcleared plots (Figure 12B). Lottia lagged slightly behind in the spring-cleared plots, but was almost directly in phase with algal cover in the fall-cleared plots (Figure 12C).

Tegula and Littorina densities at all sites were variable between treatments. After the initial high abundance of Tegula in fall-cleared plots, density decreased and remained low for more than a year (Figure 12D). Although densities the fall-cleared plot remained constant, the spring-cleared plots gradually increased through time (Figure 12D). Tegula abundance did not appear to be directly related to ephemeral cover. Littorina density fluctuations matched those of algal cover. Grazer densities and ephemeral abundance in both spring- and fall-cleared plots sharply increased during the first six months and then dropped slightly and remained level throughout the sampling period, diverging only in fall 1987 in fall-cleared plots (Figure $12 E)$.

The correlation of the variables Total Ephemeral Cover and Grazer Density at all sites was significant in the overall treatments (Table 12). All 
correlation coefficients were negative values (although not particularly large) indicating that, as the density of grazers increased, ephemeral algal cover decreased. Correlations of the variables for spring- and fall-cleared plots were not significant.

Ephemeral algae were abundant at only two sites, Sea Ranch and Pescadero Rocks, during the first 24 months of succession at both clearing times (Table 11). Grazers, however, were present at all sites, although densities varied among sites. To determine if the significant correlations in the all-sites combined test were driven by the two sites with higher ephemeral cover, data from Sea Ranch and Pescadero Rocks were combined and analyzed separately. The variables were compared seasonally and to each other using a Pearson's correlation test as they were for the all-sites combined analysis. Results from these two particular correlation matrices were not significant for any of the grazer and ephemeral variable combinations at either of the two multi-site groupings (i.e., the Sea Ranch-Pescadero Rocks grouping and the four remaining sites grouping), possibly because of low degrees of freedom. However, all variable combinations did produce negative correlation coefficients indicating an inverse relationship between grazer density and ephemeral algal cover. 


\section{DISCUSSION}

\section{Graber Density Effects}

Previous intertidal studies have indicated that high grazer densities reduce algal abundance. For example, high densities of Littorina littorea limited the abundance of perennial macroalgae, such as fucoids (Petraitis 1987). Branch and Branch (1980) showed that even low densities of the limpet, Cellana tramoserica, could control and even prevent macroalgal growth in upper intertidal pools. Negative correlations such as these were observed in my field experiments and in the multi-site study.

As grazer density increased, percent cover of early successional algae decreased. Treatments with average to high densities of grazers had significantly less total algal cover whereas treatments with grazers present at low-densities, with the exception of Tegula, had virtually no effect. The highdensity plots were devoid of nearly all ephemerals and most upright perennials throughout the study. For example, in most high density "Collisella" plots, the only available ungrazed substratum were the shells of the animals themselves, where small tufts of algae were often present. Lowdensity treatments of "Collisella," Lottia, and Littorina were overgrown to a point where the grazer could maintain only a small amount of cleared substratum in the midst of dense macroalgae. In many cases, a situation developed similar to that found by Underwood and Jernakoff (1981), where the limpet Cellana tramoserica was unable to keep the substratum clear of rapidly growing algae in the lower intertidal zone unless grazer densities 
were high. This suggests a maximum plant size and/or cover above which these grazers are no longer effective. In order for grazers to reduce algal cover or change the composition of the algal assemblage, grazing must occur during the early stages of succession when the plants are small and most susceptible to removal.

At Pescadero Point, effects of density were greatest on Porphyra spp.. At all densities, "Collisella" and Lottia were able to substantially decrease Porphyra spp. cover even after 16 months. Cover of Porphyra spp. remained high in the control treatments throughout the experiment, as did other ephemeral species. Therefore, reductions in algal cover were not merely a natural temporal variation, but rather due to the grazers effectively removing the algae when they were microscopic to only a few millimeters in size. Grazing at the holdfast may have also weakened and dislodged entire plants, maintaining bare space and creating further disturbance which prolonged successional development of the algal community.

Littorina also significantly decreased the amount of Porphyra spp. at Pescadero Point, but those reductions were only present in the low- and highdensity treatments. Although total algal cover of the multi-species assemblage was not significantly affected by Littorina in the low-density treatment, it's effect on Porphyra spp. alone was significant. At average densities however, Porphyra spp. abundance was not significantly affected. This may have been due to a possible stimulatory effect of Littorina on the growth of Porphyra spp. In the laboratory macroalgal feeding experiments, average densities were used and no changes in algal biomass were detected. Fecal materials and/or unknown secretions such as mucus were possibly 
utilized as nutrients by the algal blades. It has been shown that mucus trails from several herbivorous gastropods can stimulate microalgal (Connor and Quinn 1984) and bacterial (Peduzzi and Herndl 1991) growth. Furthermore, pedal mucus trails of "Collisella" and Lottia are adhesive and can trap microalgae and algal spores (Connor and Quinn, 1984). By retracing or crossing old trails they can ingest the mucus and any attached material, thereby utilizing another food source. This may lead to an increase in algal biomass as observed in the Littorina/Porphyra treatment. Although the enhancement abilities of Littorina mucous has not been examined, it is plausible that it may have adhesive or stimulatory qualities. As a result, the littorines may have stimulated or promoted Porphyra spp. growth such that grazer consumption rate was equaled or overshadowed by algal growth.

At Bolinas Point the effects of grazer density were greatest on juvenile stages of several perennial algal species. Although ephemerals were not abundant, lab results indicated that Tegula readily consumed them. In the field, high densities had the greatest effect and maintained cleared space for the longest duration. All densities of Tegula were effective at reducing algal cover, especially that of Fucus gardneri. Mastocarpus papillatus cover was also reduced, but only in the high-density treatments. This suggests a possible preference for Fucus over Mastocarpus These plants were grazed primarily when less than $1 \mathrm{~cm}$ in height. Once larger than this, plants apparently had a refuge in size and quickly grew to adults.

In contrast to Pescadero Point, ephemerals were not abundant and did not play a large part in algal succession at Bolinas Point. At this site, algal succession almost immediately involved the perennials Fucus gardneri and 
Mastocarpus papillatus, characteristic of the surrounding undisturbed assemblage. Although the lack of ephemerals is in contrast to findings in other successional studies (e.g., Northcraft 1948, Castenholz 1961, Menge 1976, Sousa 1980), it is not uncommon. Foster (1982) showed that the perennial, mid-intertidal algae Iridaea spp. rapidly recolonize cleared spaces without the prior establishment of ephemeral species at a site in central California. In his experiments, grazers (Tegula spp., limpets, amphipods, isopods, and crabs) retarded but did not prevent Iridaea establishment in this zone. During the first two years of succession in the multi-site study, four of the six sites also had low ephemeral algal cover even when grazer densities were low (KLI 1992). The results of my experiments done four years later were similar at two of these sites. Pescadero Point had high ephemeral cover and Bolinas Point had low ephemeral cover. These data indicated that ephemeral algal abundance varies from site to site, independent of the grazers. Control treatments without grazers at Bolinas Point did not contain ephemerals, suggesting that factors other than grazing can influence the presence or absence of algae. Those other factors were not investigated in this study, but my results show that algal succession involves a complex array of influential factors which may be largely site specific.

At both study sites, grazing activity had no significant effects on algal species richness, although there was a trend of declining number of species with increased grazer density. These results are consistent with the findings that the four grazers studied were primarily generalists, consuming whatever small plants were available. 
Overall, this study indicates that if high densities of a single grazer or an assemblage of multiple grazer species persisted for several months, ephemeral algal cover in the high intertidal zone would remain low. Also, perennial algae are vulnerable at small sizes. Should this situation exist, delays in succession and longer periods of community recovery would result simply because algae are grazed away before they grow to a large size. Succession can also be prolonged if light grazing occurs and ephemerals are abundant. Ephemerals may persist, perhaps inhibiting settlement of perennials or out-competing them for resources such as space and light (similar to the results of Lubchenco 1982). And a third outcome occurs in the presence of intermediate grazer densities. In this situation, grazers continually create variable sized clearings which often result in dense growths of ephemerals. However, these clearings can also provide space for perennial algae to settle, hastening the rate of succession. All of these outcomes are dependent in part upon grazer density and were observed in this study.

\section{IL Graner Species Efrects}

Herbivorous gastropods in the intertidal can prefer one or two species of algae, creating an effect specific to that grazer. For example, Littorina littorea, has a strong preference for the green algae Enteromorpha spp. in New England (Lubchenco 1978; Watson and Norton 1985) and Ulva lactuca in Scotland (Watson and Norton 1985). Similarly, Castenholz (1961) suggested that limpets (Lottia spp.) have preferences for particular species of diatoms. In 
addition, Eaton (1968) and Kitting (1980) showed that the limpet Acmaea (=Lottia) limatula primarily consumed two species of encrusting red algae, Petrocelis middendorffii (=P. franciscana) and Hildenbrandia occidentalis in central California.

Species-specific preferences such as those described above were not common for the four grazers I examined. No one species of grazer significantly affected just one algal species throughout the all experiments. Some preferences were noted, however, in some experiments. For example, in the macroalgal grazing experiments, Tegula consumed both UNva lobata and Porphyra spp. but consumed Ulva faster. Littorina also consumed more Ulva than Porphyra in the macroalgal grazing experiments, but the opposite was found in field experiments. In this case, it is quite possible that despite Littorina 's apparent "preference" for Ulva, Ulva was able to grow fast enough so that any grazing effects were masked.

At Pescadero Point, Littorina significantly decreased Porphyra spp. cover relative to control plots after 16 months. At this stage of succession, Porphyra was the most abundant alga in most treatment plots, growing in thick patches with few other algal species. Qualitative observations indicated that Littorina preferred this foliose habitat to bare rock or microalgal films. Littorina densities were higher and less variable when Littorina was able to inhabit densely packed moist sheets of Forphyra Porphyra typically occurs higher in the intertidal zone than Ulva (Abbott and Hollenberg 1976) perhaps because 1) limpets occurring at slightly higher tidal elevations almost exclusively graze the rock surface for microalgae (Castenholz 1961; Eaton 1968; Kitting 1980; Branch and Branch 1980; Underwood and Jernakoff,1981), and 2) 
Tegula consumes macro-sized ephemerals, especially Ulva (Best 1964; Tarpley, pers. obs.). Consequently, Porphyra is probably encountered more often by Littorina and may be used both as the typical in situ food source and as a refuge. If this is so, then when multiple algal species are available for grazing, as in the field experiments, the grazers may consume the alga most familiar and most available.

Each grazer species (with the exception of Lottia) decreased the number of algal species present and total algal cover at both sites. This was especially evident with Tegula at Bolinas Point. A number of rare species (all perennials) present in limpet and control plots were absent in the Tegula treatments, presumably due to Tegula's high consumption. At Pescadero Point, treatments with "Collisella" and Littorina present had less total algal cover than control plots without grazers. The treatment with Lottia, however, showed no effect on the algae. But this result may actually have been an artifact of the logistical difficulties of maintaining consistent Lottia densities. The number of Lottia within the treatment plots was not as consistent as with the other grazer species, possibly due to slightly lower tidal elevations and increased wave exposure that were not detected until after the experiments were in progress. However, lab studies indicated that Lottia and "Collisella" were very similar, suggesting that had densities been consistent Lottia 's impact would be similar to that of "Collisella."

Results from the multi-site study support these findings. Grazers were negatively correlated with the total ephemeral cover in disturbed plots. Regardless of the time of clearing, fluctuations in "Collisella" and Lottia densities were directly associated with differences in algal cover, whereas 
Tegula and Littorina densities were independent of ephemeral abundance. Their density was not directly affected by algal cover probably because of their ability to feed on a variety of algal foods of different sizes. In all cases, all species were present and able to significantly reduce algal cover.

\section{Algal Treferences" and Consumption Rates of Grazers}

Grazer-algal interactions that were most consistent throughout this study were grazers feeding on algae based not on species, but on plant size and whether they were ephemeral or perennial. For example, "Collisella" and Lottia avoided macroalgae in the laboratory, but actively grazed microalgae on the settling plates and in the field. These results are similar to those of Castenholz (1961), Eaton (1968), Dayton (1971), and Nicotri (1977) who showed that numerous limpet species graze diatoms, blue-green algae, and spores of macroscopic algae. This would be expected, according to Steneck and Watling (1982), because the morphology of many grazers, especially limpets, restricts their herbivory to small plants and microalgae. As a result, their potential to affect early algal succession is increased.

The preference for smaller-sized algae both in the field and in the lab was not only indicated by the consumption of ephemeral microalgae, but also by the consumption of juvenile perennials in the field experiments. Tegula affected the abundance of the perennials Fucus and Mastocarpus at Bolinas Point (Figure 7). Tegula reduced Fucus and Mastocarpus cover relative to controls and to other grazers. Observations indicated that grazing occurred when plants were generally less than five millimeters. Many other juvenile 
perennial species such as Cryptosiphonia woodii, Analipus japonicus, Polysiphonia spp., and Fterosiphonia spp., also appeared to be grazed by Tegula. Lubchenco (1982) showed that Littorina littorea and Acmaea (=Lottia) testudinalis directly affected the abundance of Fucus vesiculosus in intertidal pools on the east coast. Watson and Norton $(1985,1987)$ and Petraitis (1987) working with several species of Littorina determined it's preference for algal spores and germlings. By affecting perennial species at a small size, these generalist grazers can affect the establishment of later successional stages and also subsequent successional patterns and processes.

Based on the grazers' preference for microalgae (especially ephemerals), mean consumption rates, and because grazer density affects total algal cover, I developed a system of grazer equivalents or "mean grazer units." With this system, the cumulative effects of grazers, with similar feeding habits and algal preferences, on the surrounding algal community can be addressed by summing their respective contributions to algal removal. Ultimately, this can be used as an aid to predict the effects of grazers on algal succession.

To create this system, data from the laboratory microalgal and macroalgal feeding experiments were used separately. Direct comparisons between the two systems of mgu's and a standard conversion factor were not possible because different techniques were used to measure consumption. Results from the field experiments also were not used because the amounts of algae present were not controlled and their abundance was measured in percent cover (a unit too gross to use in calculating consumption rates and determining mgu's). 
Since Tegula consistently consumed the most algae in all experiments (Figure 9; Tables 9 and 10), it was used as if representative of one grazer unit. With 1 Tegula equal to 1 mgu, 2.4 Lottia equaled 1 Tegula (or, 1 Lottia $=0.42$ mgu); 3.7 "Collisella" equaled 1 Tegula (or, 1 "Collisella" = $0.27 \mathrm{mgu}$ ); and 14.2 Littorina equaled 1 Tegula (or, 1 Littorina $=0.07 \mathrm{mgu}$ ). Because Lottia and "Collisella" behaved similarly in most experiments and their consumption rates and preferences were not significantly different, they were combined to represent high intertidal limpets. The overall value for limpets would then be $0.34 \mathrm{mgu}$, or 2.9 limpets are equivalent to 1 Tegula. As might be expected, trends based on mean consumption rates indicated that these values are proportional to grazer body size. Tegula, being the largest of the four grazers, had the highest consumption rate, and Littorina, the smallest grazer, had the lowest rate (Figure 9). Consumption rates of the two limpet species were midrange. These results are similar to those of Geller (1991) who found that consumption was related to body size in Littorina plena in northern California.

Mean grazer units for the consumption of macroalgal species were also based on Tegula, but were only calculated for Tegula and Littorina. Due to the unclear results of the Littorina/Porphyra feeding experiment (Tables 8 and 9), mgu values were not calculated for Littorina grazing on Porphyra. However, when grazing on Ulva lobata, with Tegula representing $1 \mathrm{mgu}$, it would take approximately 18 Littorina to equal the grazing effects of one Tegula, or, one Littorina equaled $0.05 \mathrm{mgu}$. This mgu for Littorina is almost identical to its mgu value for microalgae, suggesting that both grazer species feed at similar rates regardless of whether they are feeding on micro- or macroalgae. The 
two limpet species were not included here because changes in algal biomass due to grazing were not detected for either macroalgal species (Ulva or Porphyra). Therefore, it could be assumed that they have little to no effect on these algal species with thalli of this particular size or that their consumption rates were masked by growth rates of the algae during the experiment. In this case, both "Collisella" and Lottia receive a value of $0 \mathrm{mgu}$ for the consumption of macroalgae.

In summary, herbivorous gastropods of varying densities can hasten or prolong the rate of early algal succession on high intertidal shores. By consuming small ephemeral and, in some cases, perennial algae, grazers can alter the abundance and composition of algal species present and the resulting community structure. However, the magnitude of such effects are also site specific and most likely involve other factors influencing ephemeral algal abundance and grazer densities. Results suggest that because of the complexity and variability of high intertidal shores, broad geographic generalizations regarding the effects of plant-herbivore interactions on algal succession cannot be made. 


\section{LITERATURE CITED}

Abbott, I.A. and G.J. Hollenberg. 1976. Marine algae of California. Stanford University Press, Stanford, CA $827 \mathrm{pp}$.

Anderson, B.S. 1987. Factors controlling the distribution of the high intertidal green alga, Prasiola meridionalis. Unpublished M.Sc. Thesis. San Jose State University, CA. 51 pp.

Best, B.A. 1964. Feeding activities of Tegula funebralis (Mollusca: Gastropoda). Veliger. 6, Suppl:42-45.

Branch, G.M. 1981. The biology of limpets: physical factors, energy flow, and ecological interactions. Oceanogr. Mar. Biol. Ann. Rev. 19:235380.

Branch, G.M. and M.L. Branch. 1980. Competition between Cellana tramoserica (Sowerby) (Gastropoda) and Patiriella exigua (Lamarck) (Asteroidea), and their influence on algal standing stocks. J. Exp. Mar. Biol. Ecol. 48:35-49.

Castenholz, R.W. 1961. The effects of grazing on marine littoral diatom populations. Ecology. 42:783-794.

Clements, F.E. 1916. Plant succession: an analysis of the development of vegetation. Carnegie Institute, Washington D.C. Publication No. 242.

Connor, V.A. and J.F. Quinn. 1984. Stimulation of food species growth by limpet mucus. Science. 225:843-844.

Cubit, J.D. 1984. Herbivory and the seasonal abundance of algae on a high intertidal rocky shore. Ecology. 65:1904-1917.

Dayton, P.K. 1971. Competition, disturbance, and community organization: the provision and subsequent utilization of space in a rocky intertidal community. Ecol. Monogr. 41:351-389.

Duggins, D.O. and M.N. Dethier. 1985. Experimental studies of herbivory and algal competition in a low intertidal habitat. Oecologia (Berlin). 67:183191. 
Eaton, C.M.. 1968. The activity and food of the file limpet Acmaea limatula. Veliger. 11, Suppl:: 5-12.

Geller, J.B. 1991. Gastropod grazers and algal colonization on a rocky shore in northern California: The importance of the body size of grazers. J. Exp. Mar. Biol. Ecol. 150:1-17.

Farrell, T. M. 1988. Community stability: effects of limpet removal and reintroduction in a rocky intertidal community. Oecologia (Berlin). 75:190-197.

Foster, M.S. 1964. Microscopic algal food of Littorina planaxis Philippi and Littorina scutulata Gould (Gastropod: Prosobranchiata). Veliger 7, Suppl.:149-152.

Foster, M.S. 1982. Factors controlling the intertidal zonation of Iridaea flaccida (Rhodophyta). J. Phycol. 18:285-294.

Foster, M.S. 1992. How important is grazing to seaweed evolution and assemblage structure in the north-east Pacific? Pp. 61-85 in D.M. John et al, editors. Plant-Animal Interactions in the Marine Benthos, Systematics Association Special Volume 46, Clarendon Press, Oxford.

Foster, M.S., C. Harrold and D.D. Hardin. 1991. Point vs. photoquadrat estimates of the cover of sessile marine organisms. J. Exp. Mar. Biol. Ecol. 146:193-203.

Foster, M.S., A.P. De Vogelaere, C. Harrold, J.S. Pearse, and A.B. Thum. 1988. Causes of spatial and temporal patterns in rocky intertidal communities of central and northern California. Memoirs of the California Academy of Sciences. 9:1-45.

Haven, S.B. 1973. Competition for food between the intertidal gastropods Acmaea scabra and Acmaea digitalis. Ecology. 54:143-151.

Hawkins, S.J. and P.G. Hartnoll. 1983. Grazing of intertidal algae by marine invertebrates. Oceanogr. Mar. Biol. Ann. Rev. 21:195-282.

Kitting, C.L 1979. The use of feeding noises to determine the algal foods being consumed by individual intertidal molluscs. Oecologia (Berlin). 40:1-17. 
Kitting, C.L. 1980. Herbivore-plant interactions of individual limpets maintaining a diet of intertidal marine algae. Ecol. Monogr. 50:527550 .

Kinnetic Laboratories, Inc. (KLI). 1992. Study of the rocky intertidal communities of central and northern California. Pp. 1-163 in Final Report, Volume I. Prepared in association with the University of California, Santa Cruz, Moss Landing Marine Laboratories, and TENERA Corporation for the Pacific OCS Region, Minerals Management Service, U.S. Dept. of the Interior. Contract No. 14-120001-30057. OCS Study, MMS 91-0089.

Lubchenco, J. 1978. Plant species diversity in a marine intertidal community: importance of herbivore food preference and algal competitive abilities. Am. Nat. 112:23-29.

Lubchenco, J. 1982. Effects of grazers and algal competitors on fucoid colonization in tide pools. J. Phycol. 18:544-550.

Lubchenco, J. and S.D. Gaines. 1981. A unified approach to marine plantherbivore interactions. I. Populations and Communities. Ann. Rev. Ecol. Syst. 12:405-437.

Lubchenco, J. and B. A. Menge. 1978. Community development and persistence in a low intertidal zone. Ecol. Monogr. 48:67-94.

Menge, B. A. 1976. Organization of the New England rocky intertidal community: role of predation, competition, and environmental heterogeneity. Ecol. Monogr. 46:355-393.

Morris, D.E., D.P. Abbott and E.C. Haderlie. 1980. Intertidal Invertebrates of California. Stanford University Press. Stanford, CA. 690 pp.

Nicotri, M.E. 1977. Grazing effects of four intertidal herbivores on the microflora. Ecology. 58:1020-1032.

Nicotri, M.E. 1980. Factors involved in herbivore food preference. J. Exp. Mar. Biol. Ecol. 42:13-26.

Northcraft, R. D. 1948. Marine algal colonization on the Monterey Peninsula, California. Am. J. Botany 35: 396-404. 
Parsons, T.R, Y. Maita and C.M. Lalli. 1984. A Manual of Chemical and Biological Methods for Seawater Analysis. Pergamon Press, Oxford. Pp.101-104.

Peduzzi, P. and G.J. Herndl. 1991. Mucus trails in the rocky intertidal: a highly active microenvironment. Mar. Ecol. Prog. Ser. 75:267-274.

Peterson, C.H. and P.E. Renaud. 1989. Analysis of feeding experiments. Oecologia (Berlin). 80:82-86.

Petraitis, P.S. 1983. Grazing patterns of the periwinkle and their effect on sessile intertidal organisms. Ecology. 64(3):522-533.

Petraitis, P.S. 1987. Factors organizing rocky intertidal communities of New England: herbivory and predation in sheltered bays. J. Exp. Mar. Biol. Ecol. 109:117-136.

Ricketts, E.F., J. Calvin and J.W. Hedgpeth, and D.W. Phillips. 1985. Between Pacific Tides. Fifth edition. Stanford University Press, Stanford. 652 pp.

Sousa, W.P. 1979. Experimental investigations of disturbance and ecological succession in a rocky intertidal community. Ecol. Monogr. 49:227-254.

Sousa, W.P. 1984. Intertidal mosaics: patch size, propagule availability, and spatially variable patterns of succession. Ecology. 65:1918-1935.

Southward, A.J. 1964. Limpet grazing and the control of vegetation on rocky shores. Pp. 265-273 in D. J. Crisp, editor. Grazing in terrestrial and marine environments. Blackwell Press, Oxford.

Steneck, R.S. and L. Watling. 1982. Feeding capabilities and limitation of herbivorous molluscs: a functional group approach. Mar. Biol. 68:299319.

Underwood, A.J. 1979. The ecology of intertidal gastropods. Adv. Mar. Biol. 16:111-210.

Underwood, A.J. and P. Jernakoff. 1981. Effects of interactions between algae and grazing gastropods on the structure of a low-shore intertidal community. Oecologia (Berlin). 48:221-233. 
Watson, D.C., and T.A. Norton. 1985. Dietary preferences of the common periwinkle Littorina littorea (L). J. Exp. Mar. Biol. Ecol. 88:193- 211.

Watson, D.C and T.A. Norton. 1987. The habitat and feeding preferences of Littorina obtusata (L) and L mariae Sacchi et Rastelli. J. Exp. Mar.

Biol. Ecol. 112:61-72.

Winer, B.J. 1971. Statistical principles in experimental design. Second edition. McGraw-Hill, New York 907pp. 
Table 1. Grazer species and densities used in each treatment at Pescadero Point and Bolinas Point. 


\begin{tabular}{|c|c|c|c|}
\hline Study Site & $\begin{array}{l}\text { Grazer } \\
\text { Species }\end{array}$ & $\begin{array}{l}\text { Grazer } \\
\text { Density }\end{array}$ & $\begin{array}{c}\text { Number of } \\
\text { Grazers } / 0.0625 \mathrm{~m}\end{array}$ \\
\hline \multirow[t]{4}{*}{ Pescadero Point: } & "Collisella" scabra & $\begin{array}{l}\text { Low } \\
\text { Average } \\
\text { High }\end{array}$ & $\begin{array}{r}1 \\
6 \\
30\end{array}$ \\
\hline & Lottia digitalis & $\begin{array}{l}\text { Low } \\
\text { Average } \\
\text { High }\end{array}$ & $\begin{array}{r}1 \\
4 \\
15\end{array}$ \\
\hline & Littorina scutulata & $\begin{array}{l}\text { Low } \\
\text { Average } \\
\text { High }\end{array}$ & $\begin{array}{r}25 \\
100 \\
250\end{array}$ \\
\hline & Control & Zero & 0 \\
\hline \multirow[t]{5}{*}{ Bolinas Point: } & "Collisella" scabra & Average & 6 \\
\hline & Lottia digitalis & Average & 6 \\
\hline & Tegula funebralis & $\begin{array}{l}\text { Low } \\
\text { Average } \\
\text { High }\end{array}$ & $\begin{array}{r}1 \\
4 \\
16\end{array}$ \\
\hline & Control & Zero & 0 \\
\hline & Cage Control & Zero & 0 \\
\hline
\end{tabular}


Table 2 Significant results of analyses of variance $(p \leq 0.05)$ on the effects of grazer density on a single algal species at both sites and on each of the four sampling dates analyzed. Separate analyses were done for each grazer species. Density treatment designations for SNK multiple comparison test ( $p \leq 0.05$ ) results are ranked from lowest to highest mean algal cover. Densities connected by underlines are not significantly different from one another. For each treatment, $\mathrm{n}=4$. $\mathrm{C}=$ Control; $\mathrm{CC}=$ Cage Control; $\mathrm{L}=$ Low Density; $\mathrm{A}=$ Average Density; $\mathrm{H}=$ High Density. 


\begin{tabular}{|c|c|c|c|}
\hline Grazer & $\begin{array}{l}\text { Algal Taxon/ } \\
\text { Substratum }\end{array}$ & $\mathbf{p}$ & SNK \\
\hline \multicolumn{4}{|l|}{ Pescadero Point: } \\
\hline $\begin{array}{l}4 \text { months } \\
\text { Littorina scutulata }\end{array}$ & Diatoms & 0.0003 & $\begin{array}{lll}\mathrm{C} & \mathrm{H} & \mathrm{L}\end{array}$ \\
\hline $\begin{array}{l}16 \text { months } \\
\text { "Collisella" scabra } \\
\text { Littorina scutulata }\end{array}$ & $\begin{array}{l}\text { Porphyra spp. } \\
\text { Porphyra spp. }\end{array}$ & $\begin{array}{l}0.0464 \\
0.0154\end{array}$ & $\begin{array}{llll}\mathrm{L} & \mathrm{A} & \mathrm{H} & \mathrm{C} \\
\underline{\mathrm{H}} & \mathrm{L} & \underline{\mathrm{A}} & \mathrm{C}\end{array}$ \\
\hline \multicolumn{4}{|l|}{ Bolinas Point: } \\
\hline $\begin{array}{l}8 \text { months } \\
\text { Tegula funebralis }\end{array}$ & Mastocarpus papillatus & 0.0422 & $\begin{array}{lllll}\mathrm{H} & \mathrm{C} & \mathrm{A} & \mathrm{L} & \mathrm{CC} \\
\end{array}$ \\
\hline Tegula funebralis & Fucus gardneri & 0.0586 & $\begin{array}{lllll}\mathrm{CC} & \mathrm{H} & \mathrm{A} & \mathrm{L} & \mathrm{C}\end{array}$ \\
\hline $\begin{array}{l}12 \text { months } \\
\text { Tegula funebralis }\end{array}$ & Mastocarpus papillatus & 0.0078 & $\begin{array}{lllll}\mathrm{H} & \mathrm{C} & \mathrm{A} & \mathrm{CC} & \mathrm{L}\end{array}$ \\
\hline $\begin{array}{l}16 \text { months } \\
\text { Tegula funebralis }\end{array}$ & Mastocarpus papillatus & 0.0169 & $\begin{array}{llllll}\mathbf{H} & \mathbf{A} & \mathrm{C} & \mathrm{CC} & \mathrm{L}\end{array}$ \\
\hline Tegula funebralis & Rock & 0.0132 & $\begin{array}{llllll}A & L & C & C & C & H\end{array}$ \\
\hline
\end{tabular}


Table 3. Significant results of analyses of variance $(p \leq 0.05)$ on the effects of grazer species on a single algal species at both sites and on each of the four sampling dates analyzed. Separate analyses were done for each density. Grazer species designations for SNK multiple comparison tests (p $\leq 0.05)$ are ranked from lowest to highest mean algal cover. Species connected by underlines are not significantly different from one another. For each treatment, $\mathrm{n}=4$. $\mathrm{C}=\mathrm{control} ; \mathrm{CC}=$ Cage Control; $\mathrm{Cs}=$ "Collisella" scabra, $\mathrm{Ld}=$ Lottia digitalis; Ls=Littorina scutulata, $\mathrm{Tf}=$ Tegula funebralis. 


\begin{tabular}{|c|c|c|c|}
\hline Density & Algal Taxon & $\mathbf{p}$ & SNK \\
\hline \multicolumn{4}{|l|}{ Pescadere Point: } \\
\hline \multicolumn{4}{|l|}{4 months } \\
\hline Average Density & Diatoms & 0.0001 & C Ld Cs Ls \\
\hline 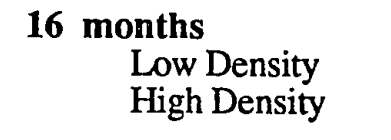 & $\begin{array}{l}\text { Porphyra spp. } \\
\text { Porphyra spp. }\end{array}$ & $\begin{array}{l}0.0093 \\
0.0083\end{array}$ & $\begin{array}{llll}\mathrm{Ls} & \mathrm{Ld} & \mathrm{Cs} \\
\mathrm{Ls} & \mathrm{Cs} & \mathrm{Ld}\end{array}$ \\
\hline
\end{tabular}

\section{Bolinas Point:}

8 months

Average Density $\quad$ Fucus gardneri $\quad 0.01^{1} \quad \underline{\text { CC Tf }} \underline{\text { C Cs Ld }}$

12 months

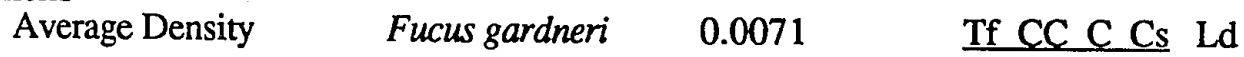

16 months

Average Density $\quad$ Fucus gardneri $0.0286 \quad$ Tf CC Cs C Ld

Results of Kruskal-Wallis nonparametric single factor ANOVA, $\mathrm{H}_{\mathrm{corr}}=9.339$ 
Table 4 Mean total algal cover ( $\% \pm 1$ S.E.) for each treatment at each site over all sampling times. Control and cage control treatments have no grazers. For grazer densities, see Table 1. Blank spaces indicate treatments not included in experimental design. For each treatment, $n=4$. 


\section{Pescadero Point:}

Grazers

4 months

"Collisella" scabra

Lottia digitalis

Littorina scutulata

Control $=67.0 \pm 23.2$

8 months

"Collisella" scabra

Lottia digitalis

Littorina scutulata

Control $=147.0 \pm 10.0$

12 months

"Collisella" scabra

Lottia digitalis

Littorina scutulata

Control $=127.0 \pm 11.8$

16 months

"Collisella" scabra

Lottia digitalis

Littorina scutulata

Control $=147.0 \pm 23.7$

\section{Duxbury Reef:}

4 months

Tegula funebralis

"Collisella" scabra

Lottia digitalis

Control $=0.0 \pm 0.0$

Cage Control $=1.0 \pm 1.0$

8 months

Tegula funebralis

"Collisella" scabra

Lottia digitalis

Control $=96.0 \pm 12.1$

Cage Control $=97.0 \pm 22.6$

12 months

Tegula funebralis

"Collisella" scabra

Lottia digitalis

Control $=117.0 \pm 1.9$

Cage Control $=126.0 \pm 13.2$

16 months

Tegula funebralis

"Collisella" scabra

Lottia digitalis

Control $=149.0 \pm 18.0$

Cage Control $=115.0 \pm 4.7$
Low

$95.0 \pm 8.4$

$96.0 \pm 6.9$

$91.0 \pm 11.0$

$135.0 \pm 10.0$

$123.0 \pm 8.1$

$151.0 \pm 9.8$

$119.0 \pm 17.5$

$115.0 \pm 7.0$

$129.0 \pm 21.1$

$109.0 \pm 15.8$

$115.0 \pm 14.9$

$92.0 \pm 9.7$

$1.0 \pm 1.0$

$59.0 \pm 13.2$

$110.0 \pm 4.2$

$98.0 \pm 10.6$
$82.0 \pm 29.0$

$121.0 \pm 33.0$

$67.0 \pm 12.2$

High

$44.0 \pm 23.3$

$97.5 \pm 5.5$

$61.0 \pm 30.1$

$51.0 \pm 38.3$

$119.0 \pm 11.5$

$114.0 \pm 15.4$

$52.0 \pm 27.0$

$90.0 \pm 27.2$

$96.0 \pm 13.5$

$57.0 \pm 16.1$

$91.0 \pm 34.4$

$98.0 \pm 33.2$

$$
\begin{aligned}
& 2.0 \pm 1.2 \\
& 0.0 \pm 0.0 \\
& 0.0 \pm 0.0
\end{aligned}
$$

$0.0 \pm 0.0$

$71.0 \pm 25.1$

$52.0 \pm 23.7$

$73.0 \pm 26.5$

$44.0 \pm 21.0$

$103.0 \pm 30.0$

$37.0 \pm 20.2$

$135.0 \pm 22.9$

$31.0 \pm 9.4$ 
Table 5. Significant results of analyses of variance $(p \leq 0.05)$ on the effects of grazer density and grazer species on total algal cover at both sites on each of the four sampling dates analyzed. Separate analyses were done for each species. Density treatment designations for SNK multiple comparison test results are ranked from lowest to highest mean total algal cover. Densities connected by underlines are not significantly different from one another. For each treatment, $n=4$. C=Control; $C C=$ Cage Control; L=Low Density; $\mathrm{A}=$ Average Density; $\mathrm{H}=$ High Density. 


\begin{tabular}{|c|c|c|}
\hline Grazer & $\mathbf{p}$ & SNK \\
\hline \multicolumn{3}{|l|}{$\begin{array}{l}\text { Grazer Density Effects } \\
\text { Pescadero Point: }\end{array}$} \\
\hline 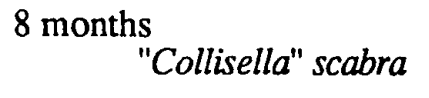 & 0.0299 & $\underline{\mathrm{H}} \mathrm{A}$ \\
\hline $\begin{array}{l}16 \text { months } \\
\text { "Collisella" scabra }\end{array}$ & 0.0333 & $\underline{\mathrm{H} \quad \mathrm{A} \quad \underline{\mathrm{L}}}$ \\
\hline \multicolumn{3}{|l|}{ Bolinas Point: } \\
\hline $\begin{array}{l}8 \text { months } \\
\text { Tegula funebralis }\end{array}$ & 0.0180 & $\mathrm{H} \quad \underline{\mathrm{A}} \quad \mathrm{L} \quad \mathrm{C} \quad \mathrm{CC}$ \\
\hline $\begin{array}{l}16 \text { months } \\
\text { Tegula funebralis }\end{array}$ & 0.0024 & $\mathrm{H} \triangle \mathrm{A} \quad \mathrm{CC} \quad \mathrm{C}$ \\
\hline \multicolumn{3}{|l|}{$\begin{array}{l}\text { Grazer Species Effects } \\
\text { Pescadero Point }\end{array}$} \\
\hline $\begin{array}{l}8 \text { months } \\
\text { Average Density }\end{array}$ & 0.0065 & Cs Ls C \\
\hline High Density & 0.0535 & Cs Ls Ld C \\
\hline
\end{tabular}

\section{Bolinas Point}

No significant difference between grazer treatments was found. 
Table 6. Mean number of algal species per plot (mean \pm 1 S.E.) for each treatment at each site over all sampling times. Control and cage control treatments have no grazers. For grazer densities, see Table 1. Blank spaces indicate treatments not included in the experimental design. For each treatment, $n=4$. 


\section{Pescadero Point:}

Grazers

4 months

"Collisella" scabra

Lottia digitalis

Littorina scutulata

Control $=1.0 \pm 0.0$

8 months

"Collisella" scabra

Lottia digitali

Littorina scutulata

Control $=2.75 \pm 0.5$

12 months

"Collisella" scabra

Lottia digitalis

Littorina scutulata

Control $=4.0 \pm 0.7$

16 months

"Collisella" scabra

Lottia digitalis

Littorina scutulata

Control $=4.5 \pm 0.9$

\section{Duxbury Reef:}

\section{4 months}

Tegula funebralis

"Collisella" scabra

Lottia digitalis

Control $=0.0 \pm 0.0$

Cage Control $=0.5 \pm 0.3$

8 months

Tegula funebralis

"Collisella" scabra

Lottia digitalis

Control $=5.8 \pm 0.5$

Cage Control $=3.3 \pm 0.9$

12 months

Tegula funebralis

"Collisella" scabra

Lottia digitalis

Control $=5.5 \pm 0.6$

Cage Control $=5.2 \pm 0.5$

16 months

Tegula funebralis

"Collisella" scabra

Lottia digitalis

Control $=5.5 \pm 0.5$

Cage Control $=4.5 \pm 1.19$
Density

Average

High

$1.8 \pm 0.5$

$1.5 \pm 0.3$

$1.2 \pm 0.3$

$1.0 \pm 0.4$

$1.25 \pm 0.3$

$2.3 \pm 0.5$

$1.5 \pm 0.3$

$1.25 \pm 0.5$

$1.5 \pm 0.6$

$3.3 \pm 0.5$

$2.75 \pm 0.3$

$3.3 \pm 0.5$

$2.3 \pm 0.3$

$1.5 \pm 0.9$

$3.3 \pm 0.5$

$2.8 \pm 0.5$

$2.5 \pm 0.6$

$2.25 \pm 0.6$

$4.0 \pm 0.4$

$2.3 \pm 0.6$

$2.75 \pm 0.5$

$3.5 \pm 0.3$

$5.0 \pm 0.4$

$2.0 \pm 1.0$

$2.8 \pm 0.8$

$2.5 \pm 0.3$

$4.0 \pm 0.4$

$3.3 \pm 0.5$

$2.8 \pm 0.2$

$2.8 \pm 0.4$

$3.3 \pm 0.5$

$2.3 \pm 0.8$

$3.5 \pm 1.2$

$3.0 \pm 1.1$

$0.2 \pm 0.2$

$0.5 \pm 0.3$

$0.0 \pm 0.0$

$0.0 \pm 0.0$

$0.0 \pm 0.0$

$2.8 \pm 1.1$

$3.0 \pm 0.7$

$1.75 \pm 0.5$

$3.8 \pm 1.4$

$5.0 \pm 0.7$

$4.25 \pm 2.5$

$4.2 \pm 1.2$

$1.0 \pm 0.4$

$6.5 \pm 1.0$

$6.5 \pm 0.3$

$3.8 \pm 0.5$

$3.5 \pm 1.2$

$1.25 \pm 0.6$

$4.8 \pm 0.6$ 
Table 7. Two-factor analyses of variance on the effects of grazer species and density on algal species richness. Only tests with statistical significance $(\mathrm{p} \leq 0.05)$ are shown. Tests at other sampling times did not show statistical differences. Values for SNK multiple comparison tests ( $p \leq 0.05$ ) are ranked from highest to lowest mean number of algal species per grazer treatment. Species connected by underlines were not significantly different from one another. 


\begin{tabular}{|c|c|c|c|c|}
\hline Source of Variation & df & MS & F-Value & $\mathbf{p}$ \\
\hline \multicolumn{5}{|l|}{$\frac{\text { Pescadero Point: }}{16 \text { months }}$} \\
\hline 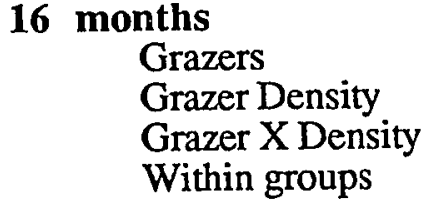 & $\begin{array}{r}3 \\
2 \\
6 \\
36\end{array}$ & $\begin{array}{l}6.78 \\
0.52 \\
0.97 \\
2.24\end{array}$ & $\begin{array}{l}3.03 \\
0.23 \\
0.43\end{array}$ & $\begin{array}{c}0.0417 \\
\text { n.s. } \\
\text { n.s. }\end{array}$ \\
\hline \multicolumn{5}{|c|}{ SNK Multiple Comparison Results: } \\
\hline Grazers: & Control & Lottia & "Collisella" & Littorina \\
\hline Density: & Control & Low & Average & High \\
\hline \multicolumn{5}{|l|}{ Bolinas Point: } \\
\hline No significant effects of $g$ & razers on & ompositic & were found. & \\
\hline
\end{tabular}


Table 8 Two-factor analyses of variance of macroalgal feeding experiments. The effects of grazer presence and algal species on the change in algal biomass were tested $(p \leq 0.05)$. The grazer factor included grazer and no-grazer treatments, and the algae factor included Ulva lobata and Porphyra spp. For all treatments, $n=12$. 


\begin{tabular}{|c|c|c|c|c|}
\hline Source of Variation & $\mathbf{d} \mathbf{f}$ & MS & F-Value & $\mathbf{p}$ \\
\hline \multicolumn{5}{|l|}{ Tegula funebralis } \\
\hline Grazer Treatment & 1 & 15588.02 & 47.04 & $p<0.0001$ \\
\hline Algae Treatment & 1 & 64974.08 & 197.18 & $\mathrm{p}<0.0001$ \\
\hline Grazer X Algae & 1 & 560.33 & 1.70 & n.s. \\
\hline Within groups & 44 & 329.52 & & \\
\hline \multicolumn{5}{|l|}{ Littorina scutulata } \\
\hline Grazer Treatment & 1 & 6.12 & 1.28 & \\
\hline Algae Treatment & 1 & 306.79 & 63.21 & 0.0001 \\
\hline Grazer X Algae & 1 & 30.48 & 6.28 & 0.0160 \\
\hline Within groups & 44 & 4.85 & & \\
\hline \multicolumn{5}{|l|}{ Lottia digitalis } \\
\hline Grazer Treatment & 1 & 499.88 & 3.88 & 0.0552 \\
\hline Algae Treatment & 1 & 33148.54 & 257.29 & 0.0001 \\
\hline Grazer X Algae & 1 & 152.65 & 1.19 & n.s. \\
\hline Within groups & 44 & 128.84 & & \\
\hline \multicolumn{5}{|l|}{ "Collisella" scabra } \\
\hline Grazer Treatment & 1 & 9.19 & 0.03 & \\
\hline Algae Treatment & 1 & 20.02 & 0.07 & n.s. \\
\hline Grazer X Algae & 1 & 0.63 & 0.002 & n.s. \\
\hline Within groups & 44 & 302.51 & & \\
\hline
\end{tabular}


Table 9. Results of SNK multiple comparison tests ( $p \leq 0.05$ ) on each grazer from the macroalgal feeding experiments. Lines connect treatments that are not significantly different from each other. Mean changes in macroalgal wet weight expressed as $\mathrm{mg} /$ individual/day ( \pm 1 S.E.). For all treatments, $\mathrm{n}=12$. 


\begin{tabular}{|c|c|c|c|c|}
\hline & \multicolumn{2}{|c|}{ Ulva lobata } & \multirow{2}{*}{$\begin{array}{l}\text { Porphyra } \\
\text { Control }\end{array}$} & \multirow{2}{*}{$\begin{array}{l}\text { spp. } \\
\text { w/grazer }\end{array}$} \\
\hline & Control & w/grazer & & \\
\hline Tegula funebralis & $-58.50 \pm 5.80$ & $-101.38 \pm 6.69$ & $8.25 \pm 2.19$ & $-20.96 \pm 5.17$ \\
\hline Littorina scutulata & $46.52 \pm 9.58$ & $23.40 \pm 7.11$ & $-19.98 \pm 3.25$ & $-11.23 \pm 3.00$ \\
\hline Lottia digitalis & $69.00 \pm 3.72$ & $71.89 \pm 2.90$ & $12.88 \pm 2.96$ & $22.90 \pm 3.45$ \\
\hline "Collisella" scabra & $-10.15 \pm 5.84$ & $-10.79 \pm 6.69$ & $-8.63 \pm 2.35$ & $-9.73 \pm 4.06$ \\
\hline
\end{tabular}


Table 10. Analyses of variance results of microalgal feeding experiments. Algal categories for SNK multiple comparison test results are sorted from lowest to highest change in percent cover. Values (mean \pm 1 S.E., $n=4$ ) connected by underlines are not significantly different from one another. Negative values represent a decrease in cover and positive values represent an increase in cover. 


\begin{tabular}{|c|c|c|c|c|}
\hline Grazer & $\mathbf{p}$ & & SNK Results & \\
\hline Tegula funebralis & 0.0013 & $\begin{array}{c}\text { Green Filaments } \\
-4,01 \pm 1,27\end{array}$ & $\begin{array}{c}\text { Diatoms } \\
1,24 \pm 4.19 \\
\end{array}$ & $\begin{array}{c}\text { Bare Plate Space } \\
24.08 \pm 5.00\end{array}$ \\
\hline "Collisella" scabra & 0.0042 & $\begin{array}{c}\text { Green Filaments } \\
0 \pm 0\end{array}$ & $\begin{array}{c}\text { Diatoms } \\
0.31 \pm 3.20 \\
\end{array}$ & $\begin{array}{c}\text { Bare Plate Space } \\
11.42 \pm 1.27\end{array}$ \\
\hline Lottia digitalis & n.s. & $\begin{array}{c}\text { Diatoms } \\
-4.32 \pm 7.17\end{array}$ & $\begin{array}{c}\text { Green Filaments } \\
0.92 \pm 0.92 \\
\end{array}$ & $\begin{array}{c}\text { Bare Plate Space } \\
7.10 \pm 9.93\end{array}$ \\
\hline Littorina scutulata & n.s. & $\begin{array}{c}\text { Diatoms } \\
-2.78 \pm 9.42 \\
\end{array}$ & $\begin{array}{c}\text { Green Filaments } \\
0 \pm 0\end{array}$ & $\begin{array}{c}\text { Bare Plate Space } \\
15.12 \pm 2.16 \\
\end{array}$ \\
\hline
\end{tabular}


Table 11. Mean ( \pm 1 S.E.) grazer densities and mean percent cover of the most abundant ephemeral algal species, and mean total ephemeral cover per plot $\left(0.1875 \mathrm{~m}^{2}\right)$ at all locations of the multi-site study after 24 months. Density values are counts. Dash (-) represents species not found at that site. NA= data not available from KLI. 


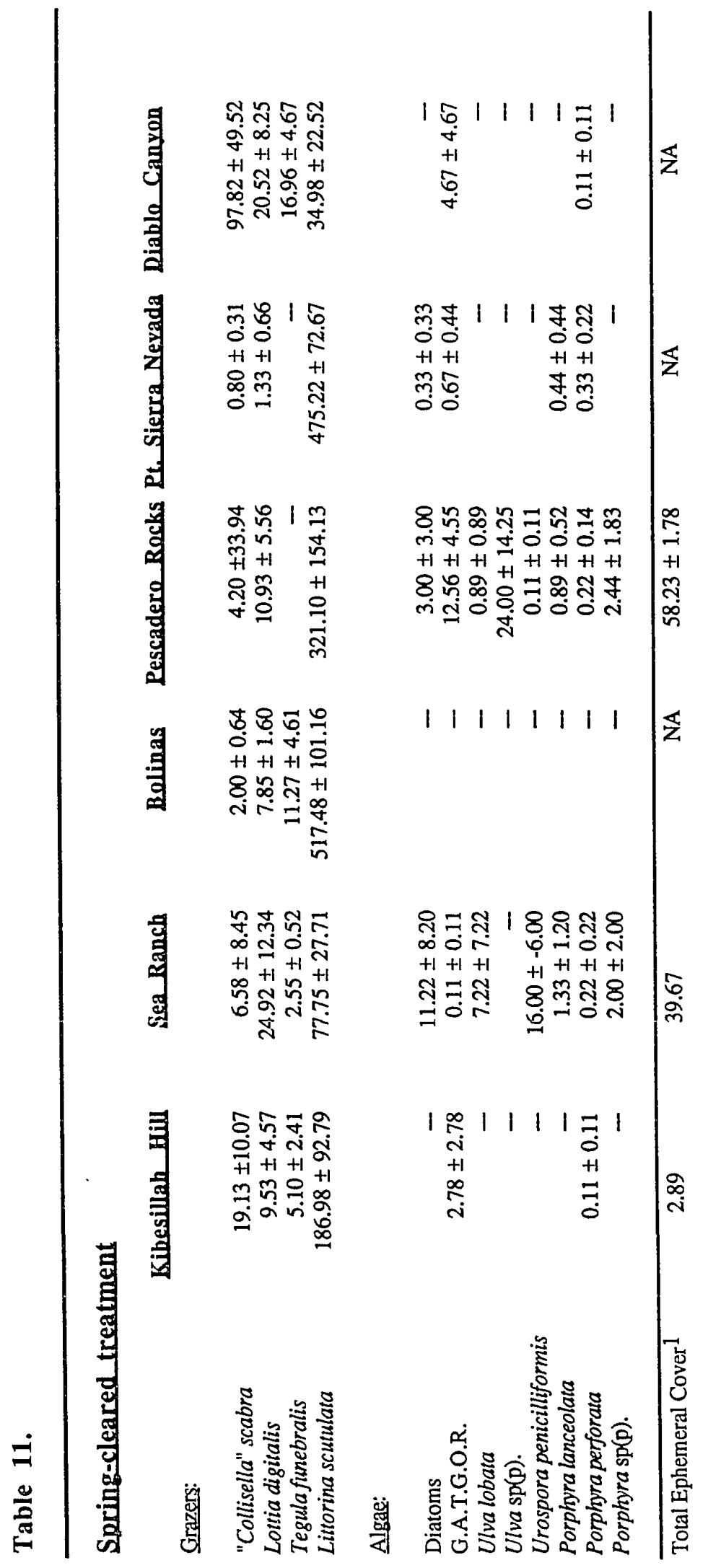




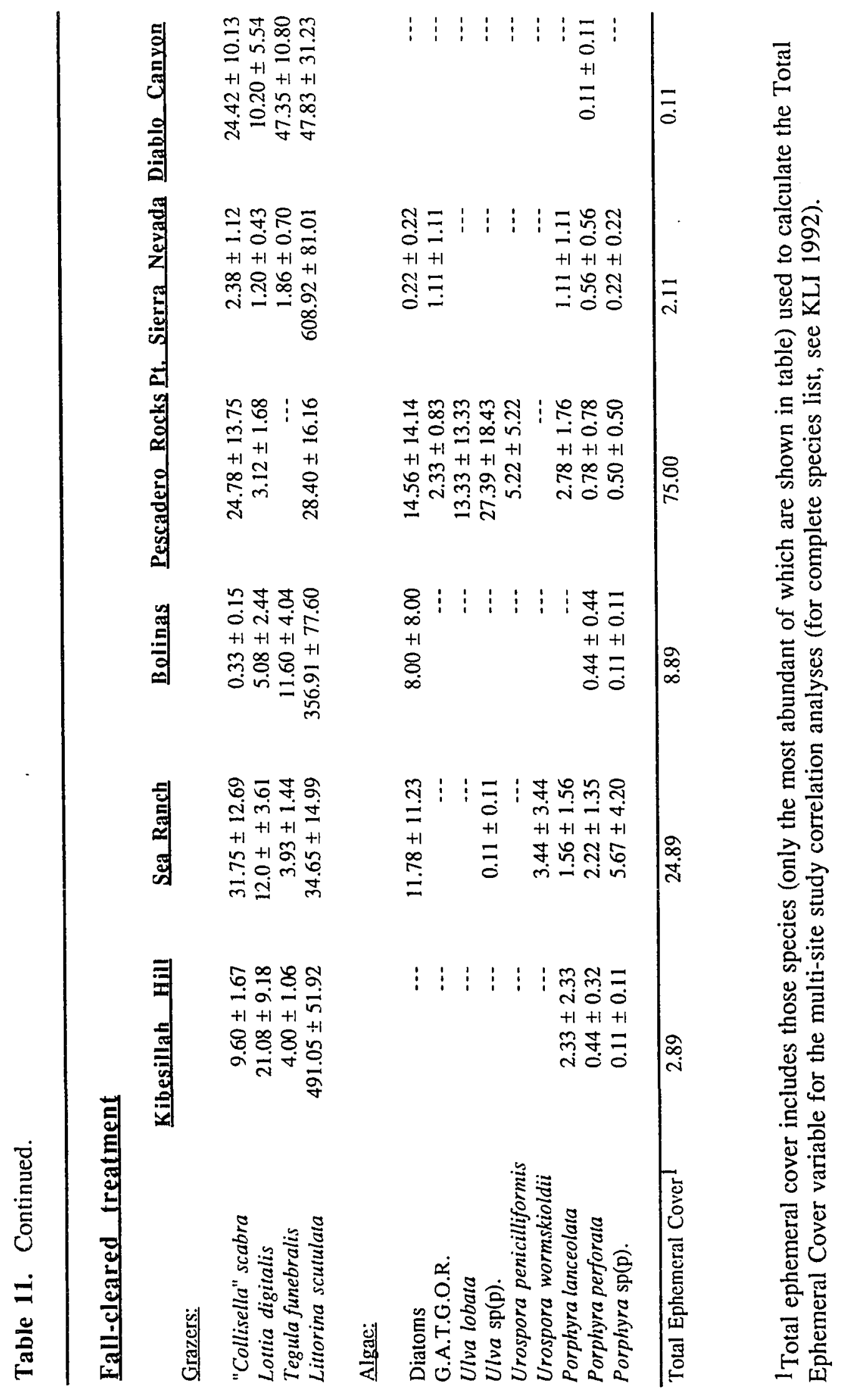


Table 12 Results of Pearson's correlation analysis of all six multi-site study locations combined. Upper numbers are correlation coefficients and numbers in parentheses are probabilities. * significant at $\mathrm{p}=0.05$. 


\begin{tabular}{llll}
\hline & Spring & Fall & Overall \\
\hline \hline & & & \\
Total Ephem. x Grazer Density & -0.26360 & -0.45633 & -0.38046 \\
& $(0.29055)$ & $(0.05698)$ & $(0.02208)^{*}$ \\
\hline
\end{tabular}

1 Overall = spring-cleared and fall-cleared treatments combined . 
Figure 1. Location of study sites: Pescadero Point in Carmel Bay $\left(36^{\circ} 33^{\prime} \mathrm{N}\right.$, $\left.121^{\circ} 57^{\prime} \mathrm{W}\right)$, and Bolinas Point $\left(37^{\circ} 54^{\prime} \mathrm{N}, 122^{\circ} 43^{\prime} \mathrm{W}\right)$ near Bolinas, California. 


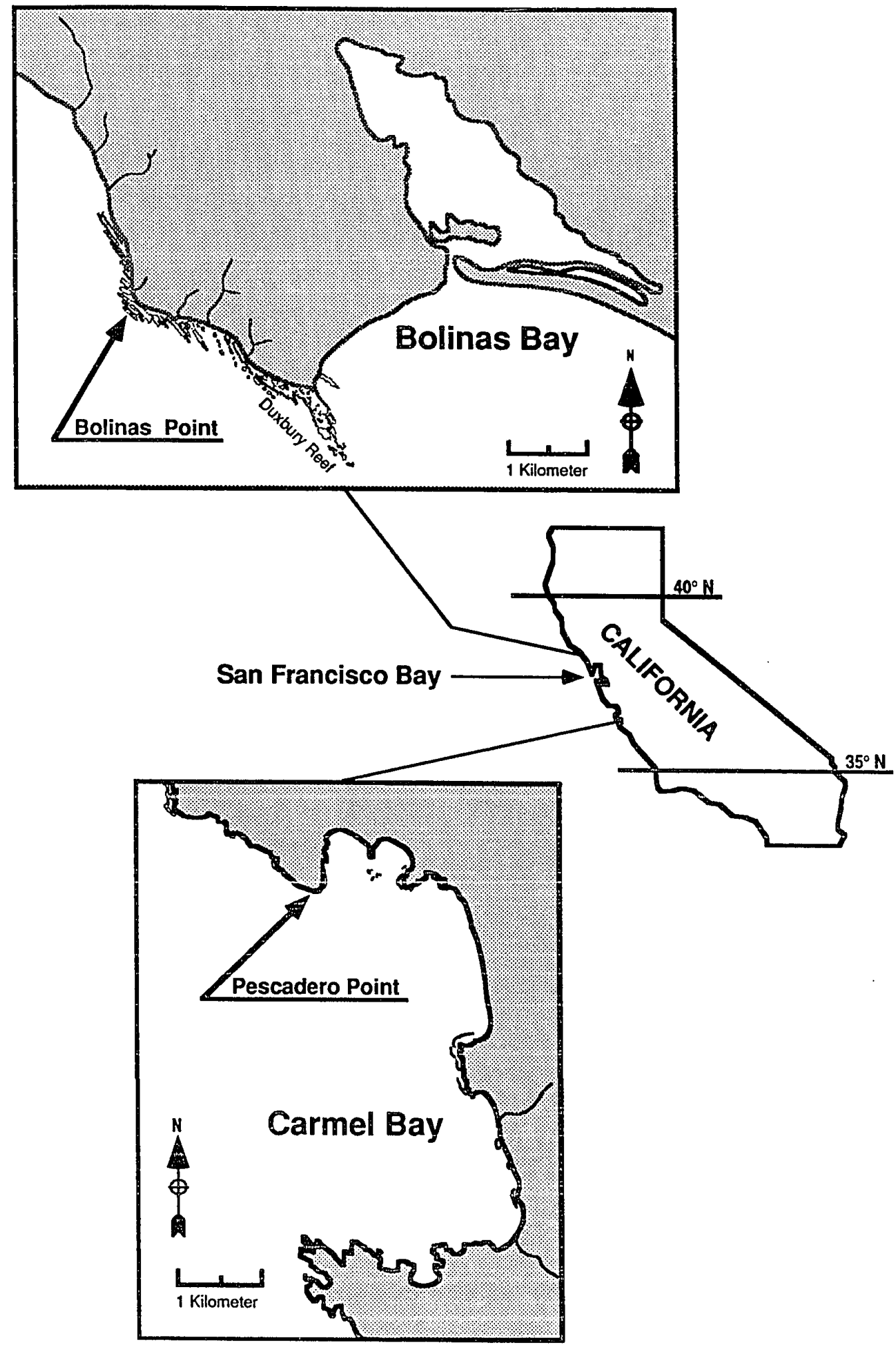


Figure 2 Treatment manipulation barriers. A) Limpet, littorine, and control barrier of astroturf and a band of sticky "Tree Tanglefoot." B) Tegula treatment cage of $1.27 \mathrm{~cm}^{2}$ stainless steel wire mesh surrounded by astroturf and "Tree Tanglefoot." Cage also has $10 \times 10 \mathrm{~cm}$ door on top for access. C) Wire mesh cage control with two open sides, surrounded by astroturf and "Tree Tanglefoot." 

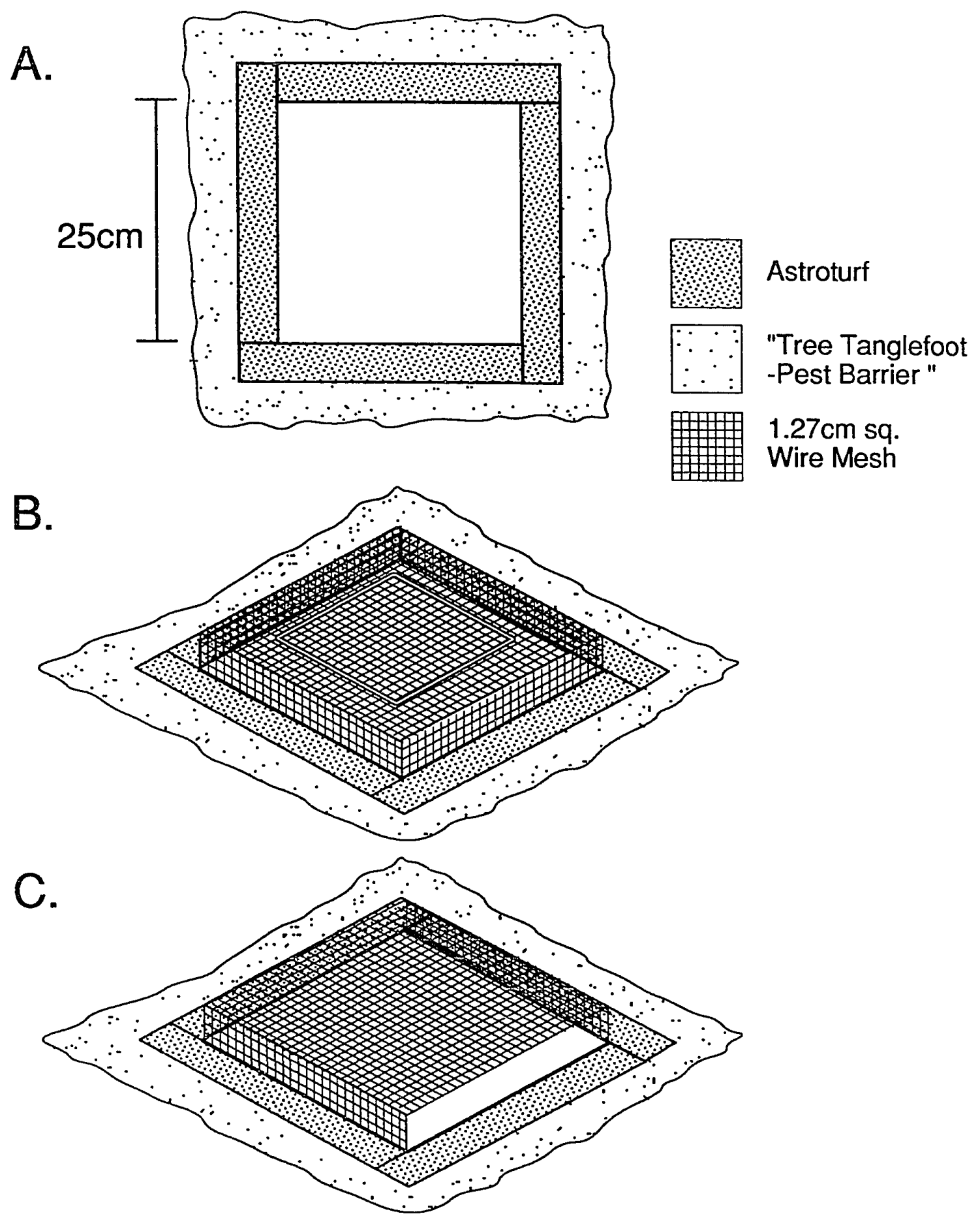
Figure 3. Diagram of laboratory apparatus used for macro-and microalgal feeding experiments. Chambers were $25 \times 25 \times 20 \mathrm{~cm}$. Not to scale. 


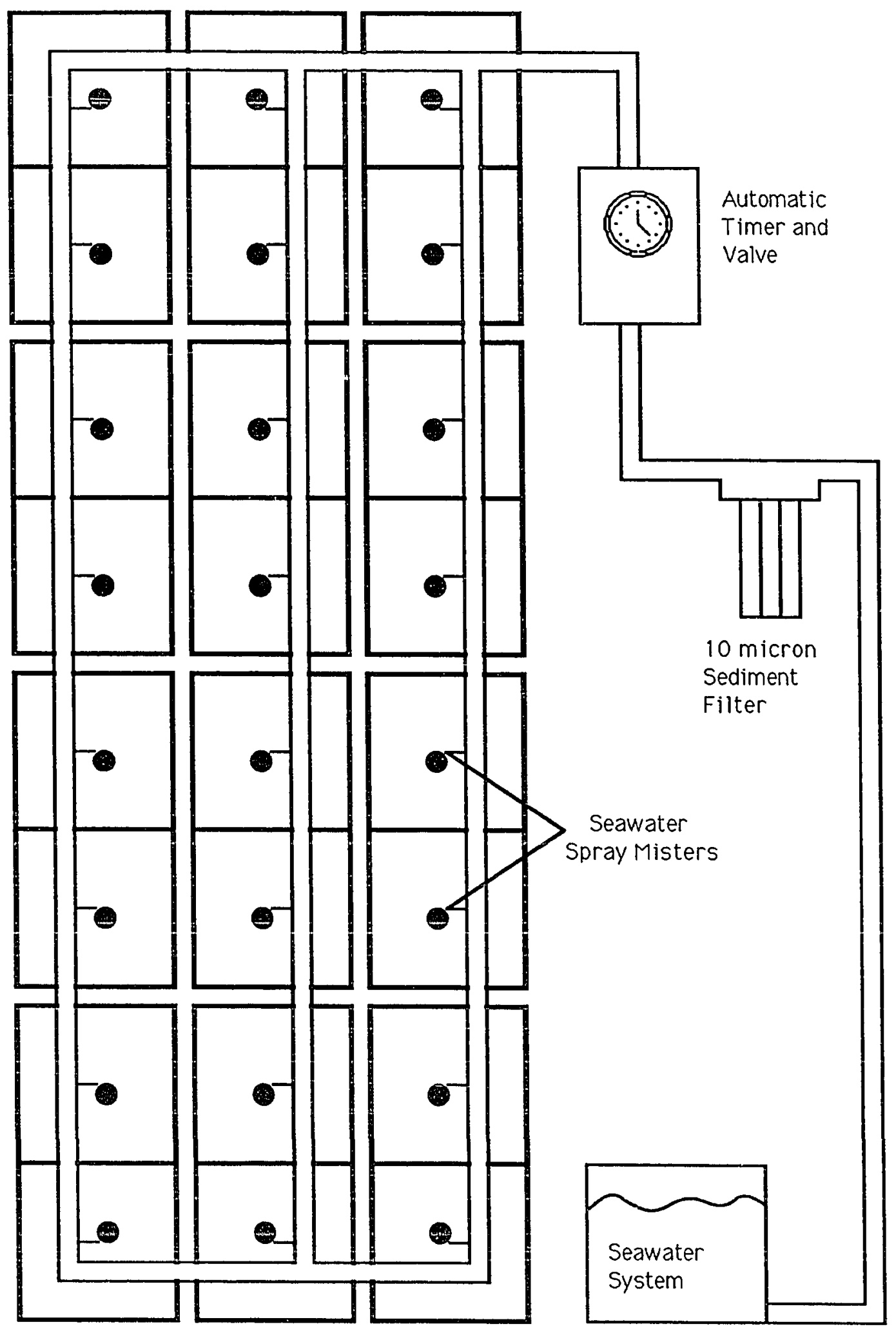


Figure 1. Early algal succession at Pescadero Point in the control treatment (no grazers). Ribbons are mean percent cover per plot through time for those species/substrata that attained greater than 10 percent cover at least once during the sampling period. For definition of GATGOR, see text. 


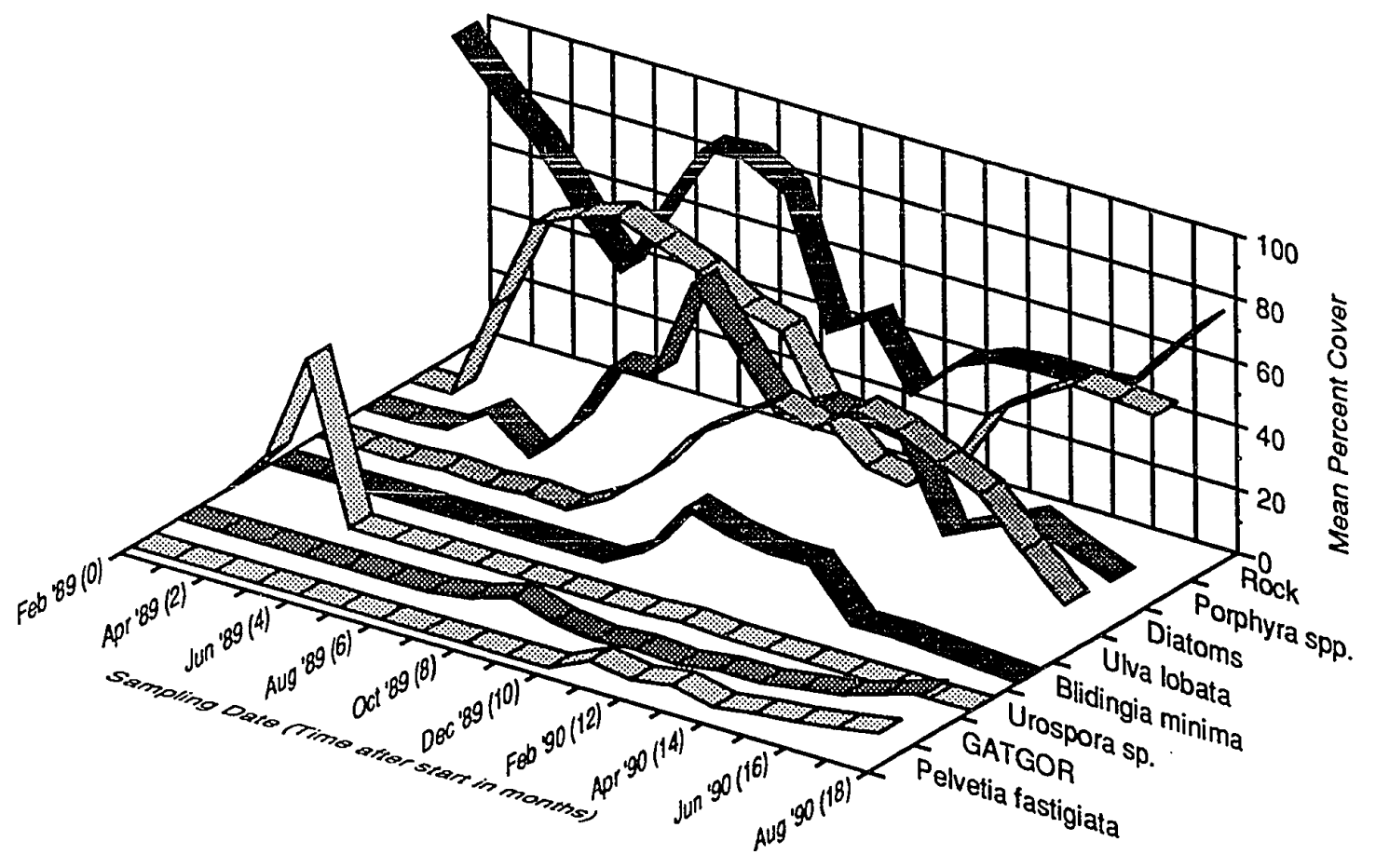


Figure 5. Early algal succession at Bolinas Point in the control and cage control treatments (no grazers). Ribbons are mean percent cover per plot through time for those species/substrata that attained greater than 10 percent cover at least once during the sampling period. 


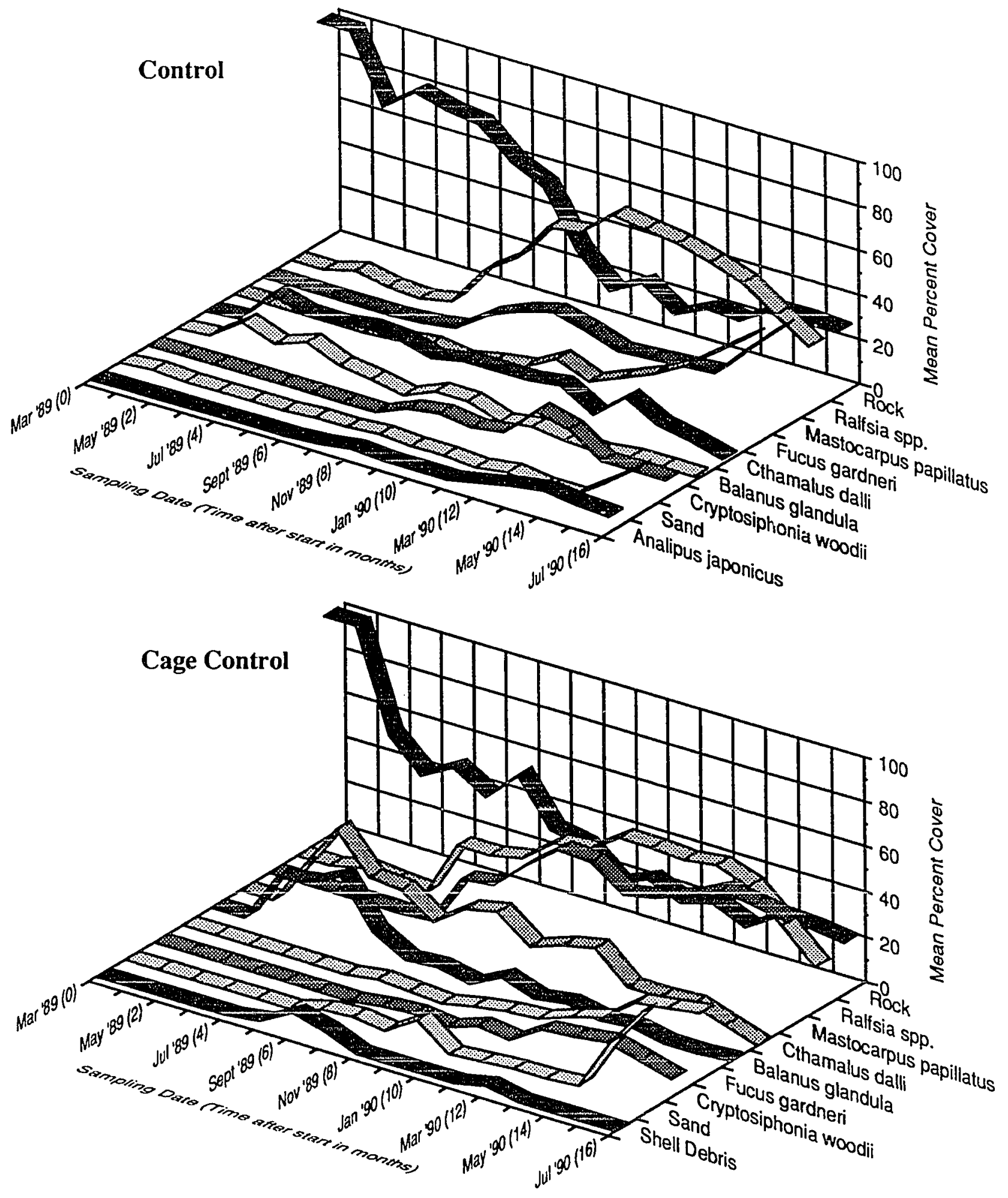


Figure 6. Mean percent cover of each algal taxon and bare rock space in each grazer density treatment at Pescadero Point on each sampling date. $\mathrm{C}=\mathrm{control}$ (no grazers); $\mathrm{L}=$ low; $\mathrm{A}=$ average; $\mathrm{H}=\mathrm{high}$; $\mathrm{C} . \mathrm{s} .=$ "C." scabra, $\mathrm{Ld}=\mathrm{L}$. digitalis, Ls. $=L$ scutulata, GATGOR=green algae that grows on rocks (see text). Error bars are omitted for clarity. Mean values and standard errors are presented in Appendix 2. For all treatments $n=4$. 

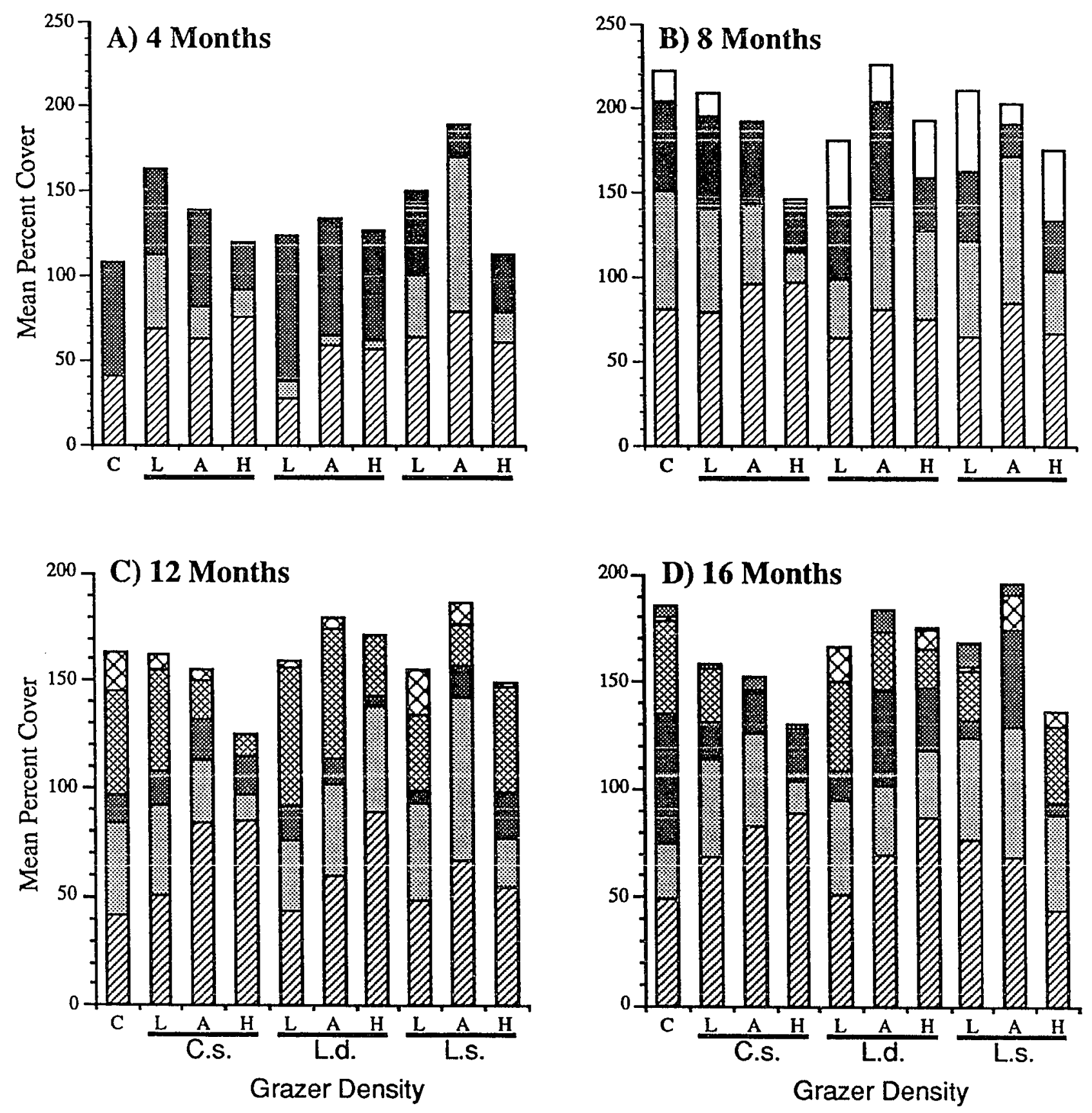

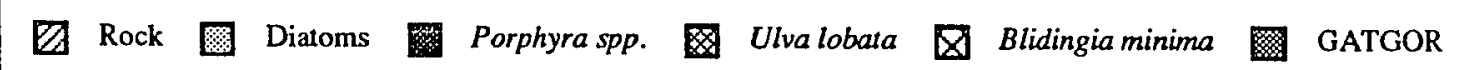


Figare 7. Mean percent cover of each algal taxon and bare rock space in each grazer density treatment at Bolinas Point on each sampling date. $\mathrm{C}=$ control (no grazers); $\mathrm{CC}=$ cage control (no grazers); $\mathrm{L}=$ low; $\mathrm{A}=$ average; $\mathrm{H}=$ high; $\mathrm{T} . \mathrm{f}=T$. funebralis, C.s.="C." scabra, Ld. $=L$ digitalis. Error bars are omitted for clarity. Mean values and standard errors are presented in Appendix 2. For all treatments $n=4$. 

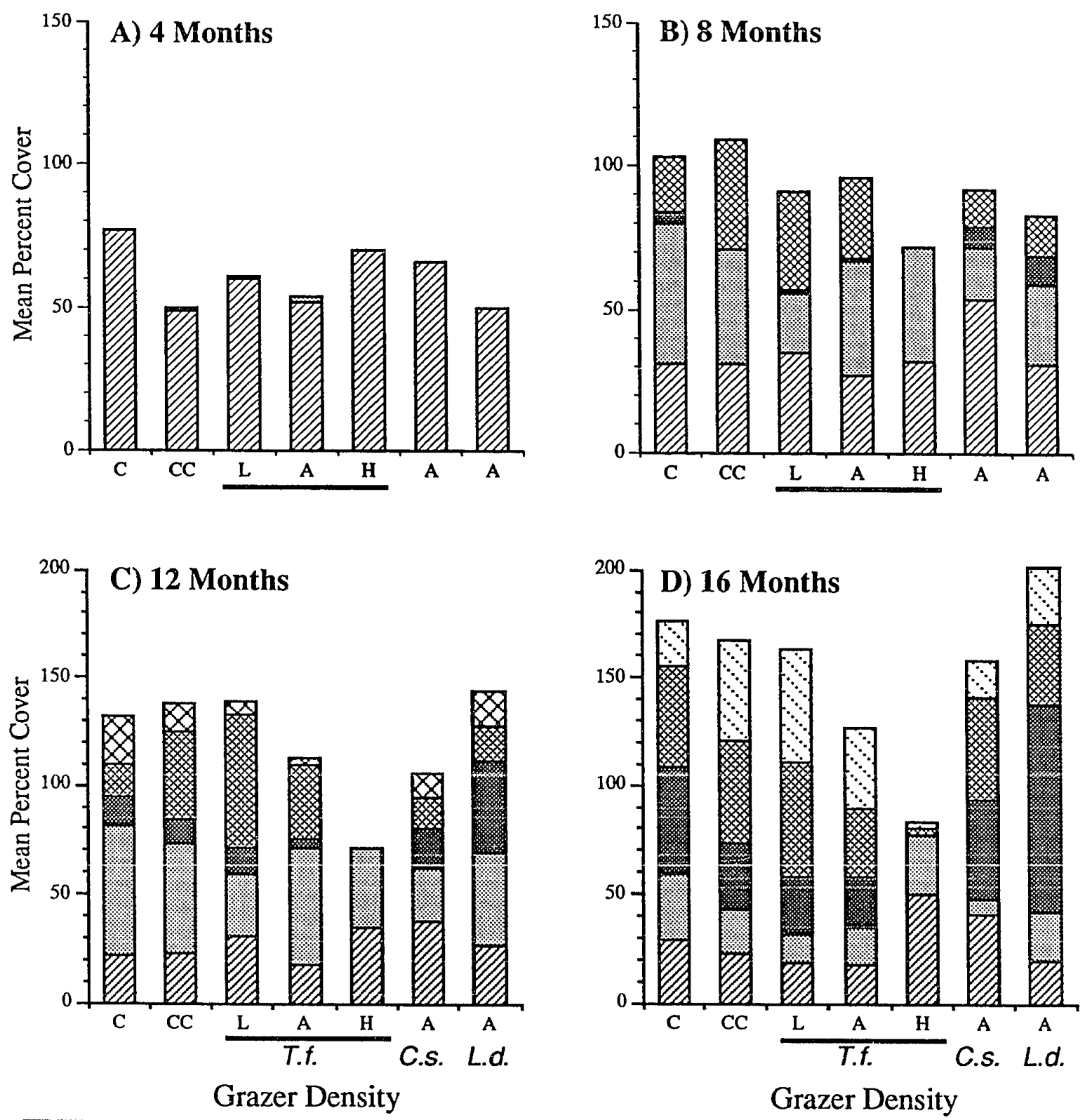

Grazer Density

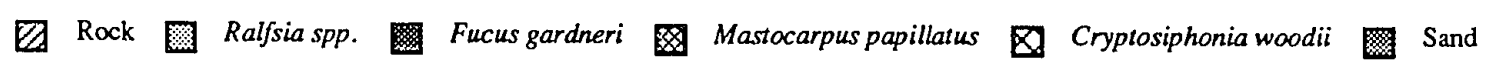


Figure 8. Mean change in macroalgal wet weight (grams) of Ulva spp. and Porphyra spp. during the four-day experiment in all control and grazer treatments. A) Tegula funebralis B) Littorina scutulata C) Lottia digitalis D) "Collisella" scabra. Error bars are \pm 1 S.E. and $n=12$. 

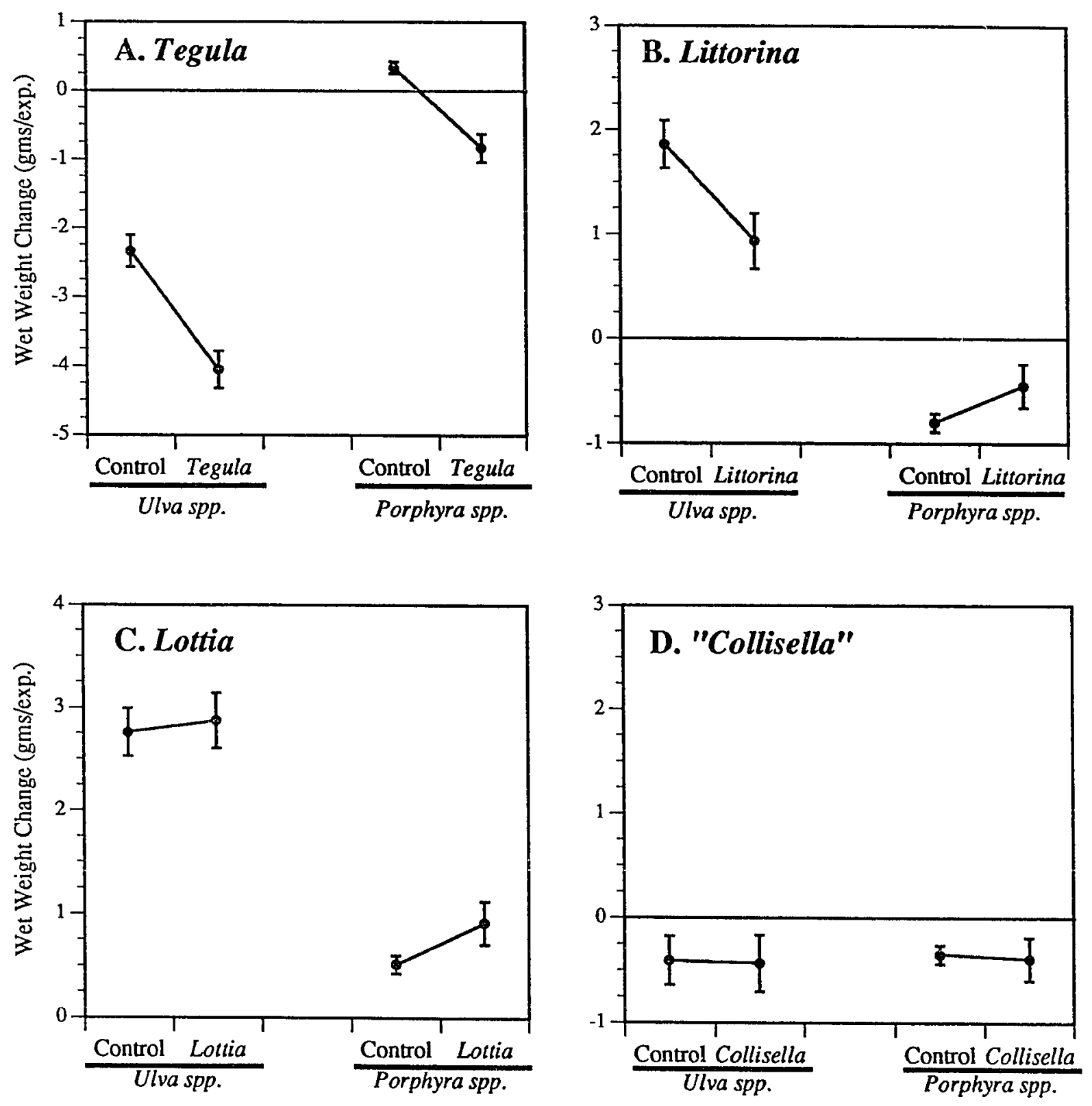
Figure 9. Mean microalgal consumption rate of each grazer during the fourday experiment. Error bars are \pm 1 S.E. and $n=4$. 


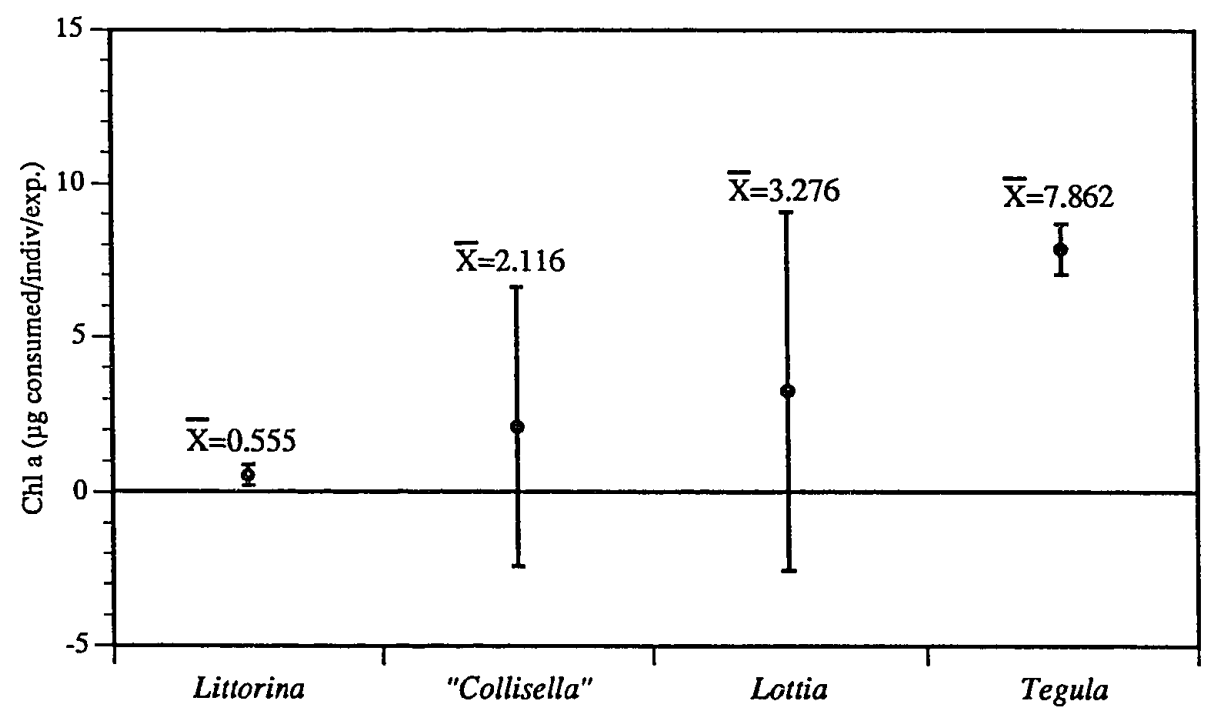


Figure 10. Mean total ephemeral cover (A) and mean grazer density $(B, C, D)$ fluctuations per plot $\left(0.1875 \mathrm{~m}^{2}\right)$ over time in the spring- and fall-cleared treatments of the multi-site study at Pescadero Rocks. Spring clearings were made in March and April 1985. Fall clearings were made in October and November 1985. 

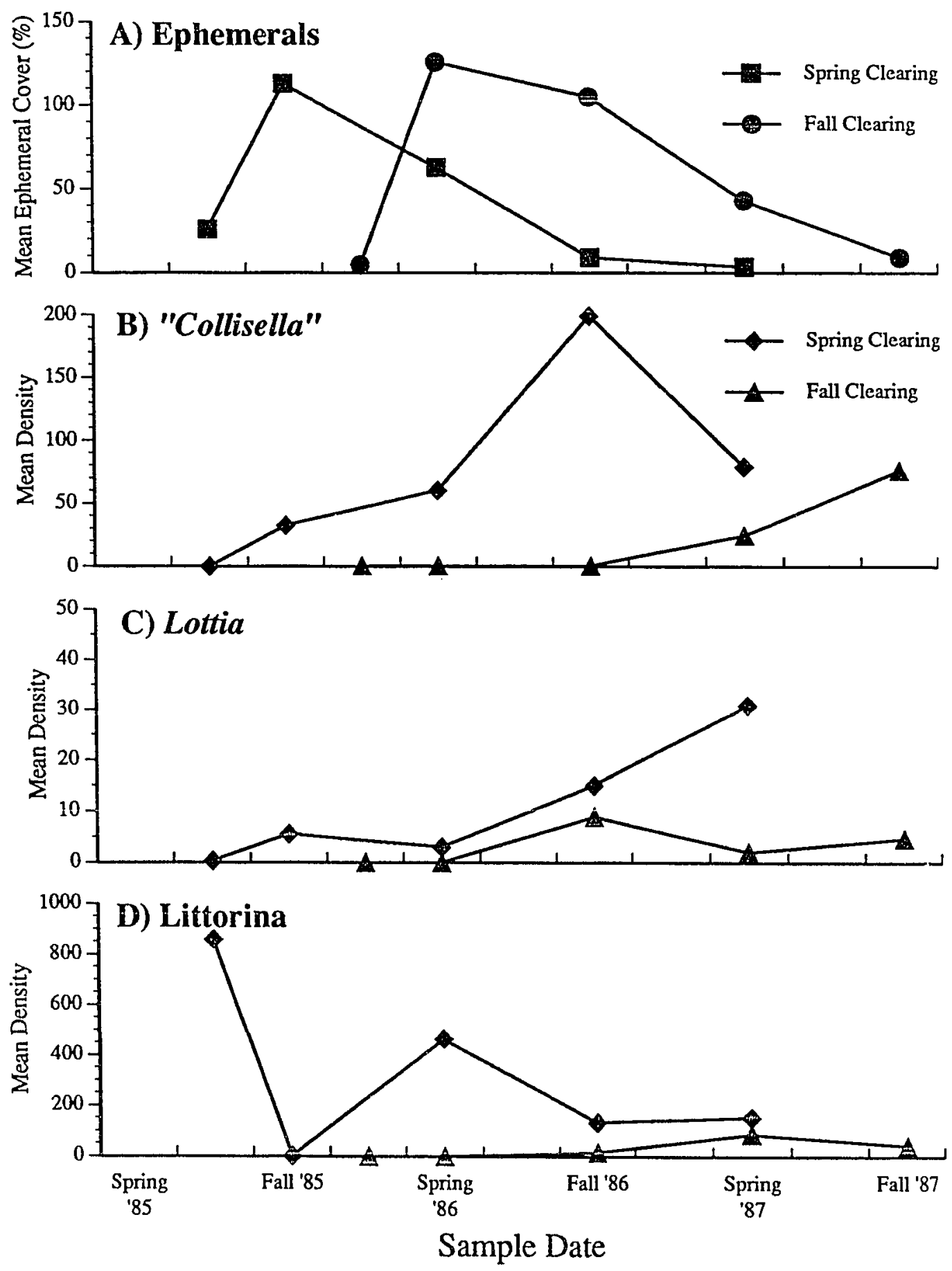
Figure 11. Mean total ephemeral cover (A) and mean grazer density $(B, C, D$, E) fluctuations per plot $\left(0.1875 \mathrm{~m}^{2}\right)$ over time in the spring- and fall-cleared treatments of the multi-site study at Bolinas. Spring clearings were made in March and April 1985. Fall clearings were made in October and November 1985. 

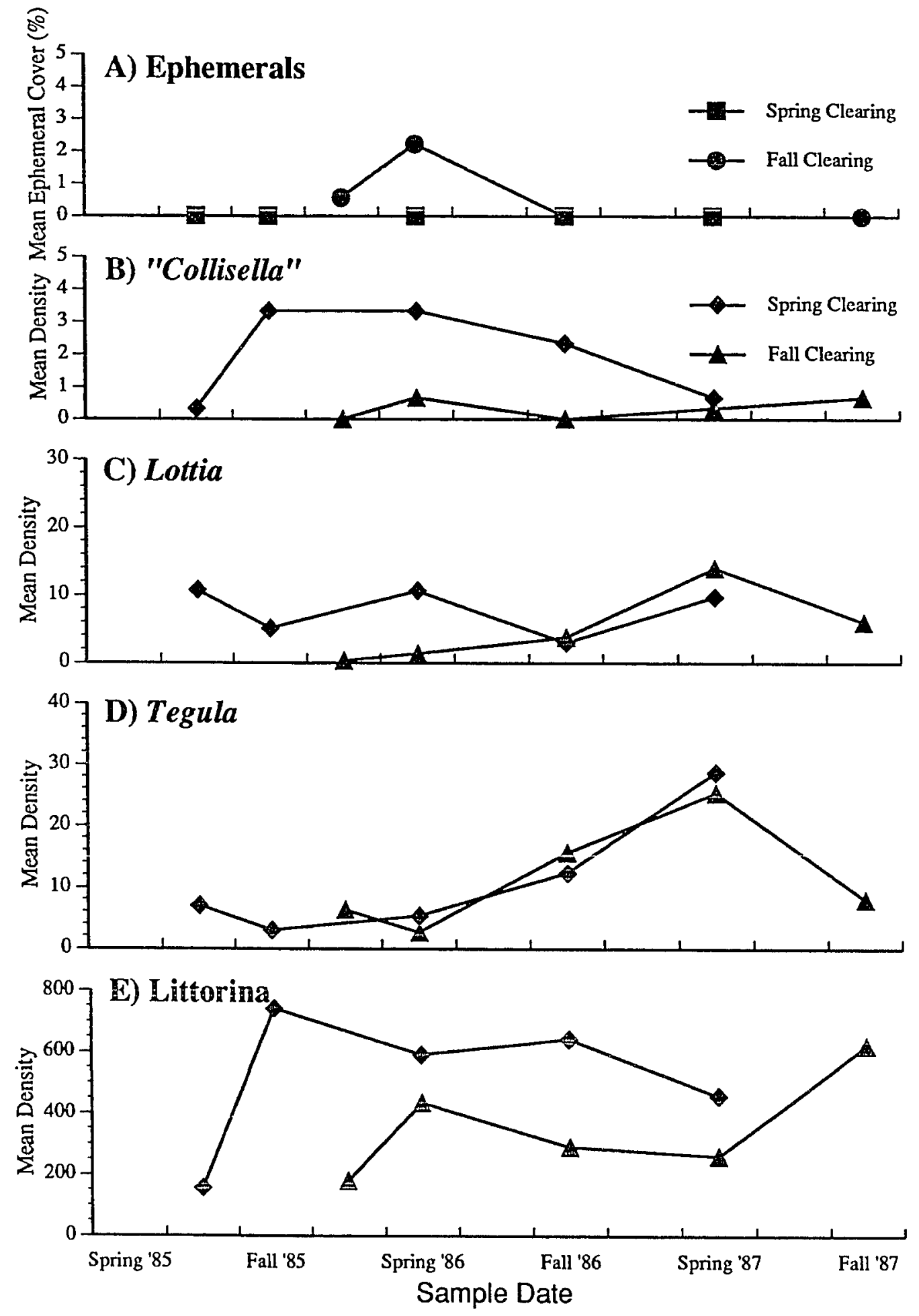
Figure 12 Mean total ephemeral cover (A) and mean grazer density (B, C, D, E) fluctuations per plot $\left(0.1875 \mathrm{~m}^{2}\right)$ of all multi-site study sites combined. Spring clearings were made in March and April 1985. Fall clearings were made in October and November 1985. 

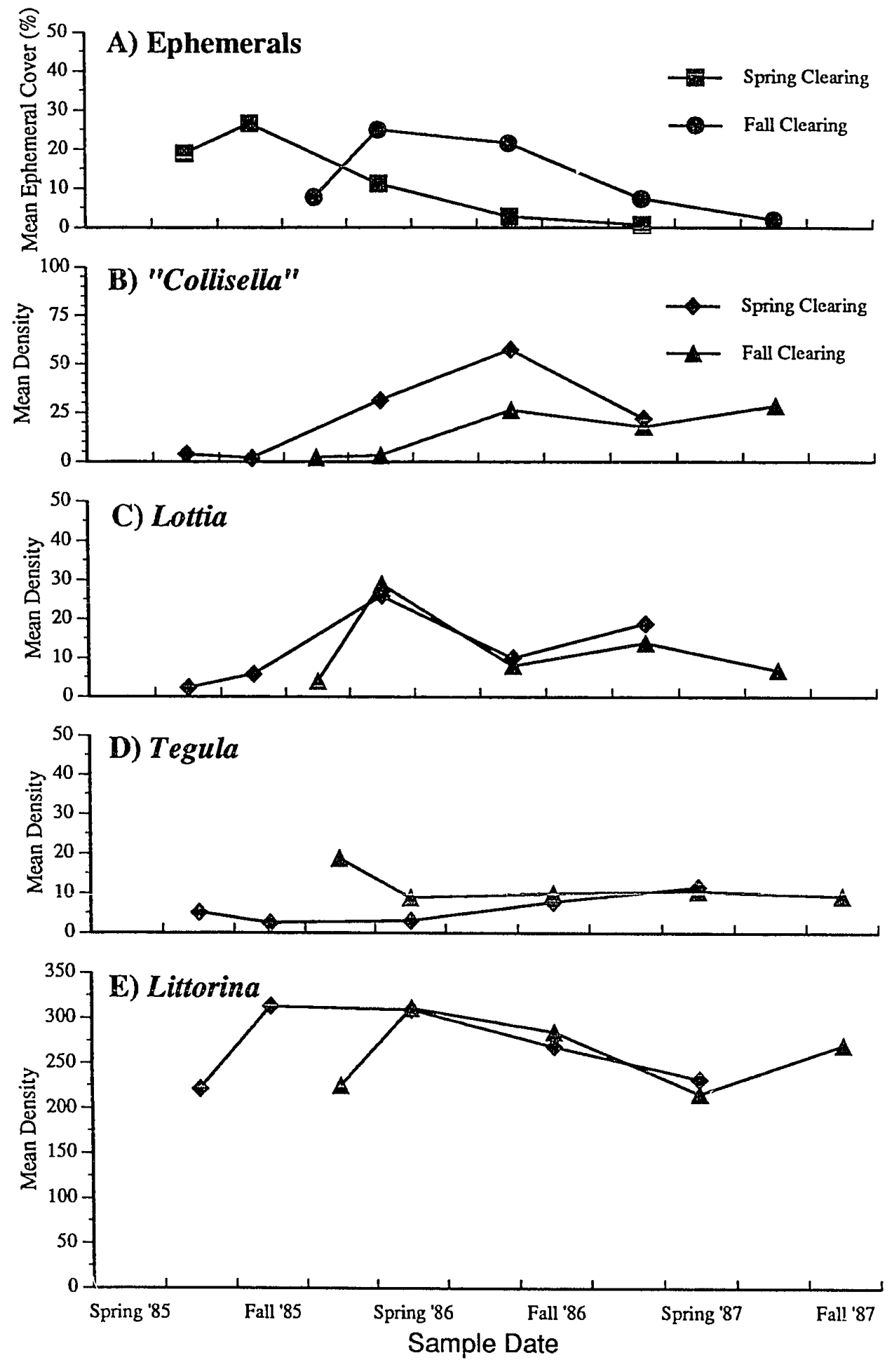
APPENDIX 1

\section{Algal Species Iisis \\ at Pescadero Point and Bolinas Point}

List of algal species found at Pescadero Point and Bolinas Point among all grazer treatments during the first 16 months of succession. 


\begin{tabular}{|c|c|}
\hline Pescadero Point & Bolinas Point \\
\hline$\frac{\text { Chrysophyta }}{\text { Diatoms 1a, } 2,3,4}$ & $\frac{\text { Chrysophyta }}{\text { Diatoms } 3}$ \\
\hline $\begin{array}{l}\text { Chlorophyta } \\
\text { Acrosiphonia coalita } 3 \\
\text { Blidingia minima 1a, } 2,3,4 \\
\text { Cladophora columbiana } 2 \\
\text { G.A.T.G.O.R. 1a, 2, 3, } 4 \\
\text { Ulva lobata } 1 \mathrm{a}, 2,3,4 \\
\end{array}$ & $\begin{array}{l}\text { Chlorophyta } \\
\text { Cladophora columbiana } 1 \mathrm{a}, 1 \mathrm{~b}, 235 \\
\text { Urospora sp. } 1 \mathrm{~b}\end{array}$ \\
\hline $\begin{array}{l}\text { Rhodophyta } \\
\text { Bangia fusco-purpurea } 4 \\
\text { Callithamnion pikeanum } 3 \\
\text { Ceramiun eatonianum } 2,3,4 \\
\text { Corallina sp. } 3 \\
\text { Corallina vancouveriensis } 3 \\
\text { Endocladia muricata } 1 \mathrm{a}, 2,4 \\
\text { Gelidium coulteri } 2 \\
\text { Gelidium pusillum } 2 \\
\text { Iridaea splendens } 2,3,4 \\
\text { Mastocarpus papillatus } 2,3,4 \\
\text { Petrocelis sp. } 4 \\
\text { Pink Crust } 2,3,4 \\
\text { Polysiphonia hendryi } 2,4 \\
\text { Polysiphonia pacifica } 4 \\
\text { Porphyra perforata } 1 \mathrm{a}, 2,3,4 \\
\text { Red Filament } 2\end{array}$ & $\begin{array}{l}\text { Rhodophyta } \\
\text { Cryptosiphonia woodii 1a, 1b, 2, 3, } 5 \\
\text { Endocladia muricata } 1 \mathrm{a}, 1 \mathrm{~b}, 2,3,5 \\
\text { Gelidium coulteri } 1 \mathrm{a}, 1 \mathrm{~b}, 2 \\
\text { Gelidium pusillum } 2 \\
\text { Iridaea splendens } 1 \mathrm{a} \\
\text { Iridaea heterocarpa } 1 \mathrm{a}, 1 \mathrm{~b}, 2,3,5 \\
\text { Mastocarpus papillatus } 1 \mathrm{a}, 1 \mathrm{~b}, 2,3,5 \\
\text { Microcladia borealis } 2 \\
\text { Neorhodomela larix } 2 \\
\text { Odonthalia floccosa } 1 \mathrm{a} \\
\text { Pink Crust } 1 \mathrm{a}, 5 \\
\text { Polysiphonia hendryi } 1 \mathrm{a}, 1 \mathrm{~b}, 2,3,5 \\
\text { Polysiphonia nathaniellii 1a, } 3 \\
\text { Polysiphonia paniculata 1a, } 2,3 \\
\text { Polysiphonia sp. } 2,3,5 \\
\text { Porphyra sp. } 1 \mathrm{~b}, 2 \\
\text { Pterosiphonia bipinnata } 1 \mathrm{a}, 1 \mathrm{~b}, 2,3,5 \\
\text { Pterosiphonia dendroidea } 1 \mathrm{a}, 2,3 \\
\end{array}$ \\
\hline $\begin{array}{l}\text { Phaeophyta } \\
\text { Fucus gardneri } 1 \mathrm{a}, 3,4 \\
\text { Hesperophycus harveyanus } 3 \\
\text { Pelvetia fastigiata } 1 \mathrm{a}, 2,3,4\end{array}$ & $\begin{array}{l}\text { Phaeophyta } \\
\text { Analipus japonicus } 1 \mathrm{a}, 1 \mathrm{~b}, 2,3,5 \\
\text { Cylindrocarpus rugosus } 2,5 \\
\text { Fucus gardneri } 1 \mathrm{a}, 1 \mathrm{~b}, 2,3,5 \\
\text { Leathesia difformis } 1 \mathrm{a}, 1 \mathrm{~b}, 2,3,5 \\
\text { Pelvetia fastigiata } 3 \\
\text { Ralfsia sp. 1a, } 1 \mathrm{~b}, 2,3,5\end{array}$ \\
\hline \multicolumn{2}{|c|}{$\begin{array}{l}\text { 1a = present in control treatment; } 1 \mathrm{~b}=\text { present in cage control treatment; } 2=\text { present in } \\
\text { "Collisella" scabra treatment; } 3=\text { present in Lottia digitalis treatment; } 4=\text { present in } \\
\text { Littorina scutulata treatment; } 5=\text { present in Tegula funebralis treatment; G.A.T.G.O.R. } \\
\text { Green Algae That Grows On Rocks (see text for further details). }\end{array}$} \\
\hline
\end{tabular}




\title{
APPENDIX 2 \\ Algai Cover and Rock Space Results in Each Treatment at Pescadeno Point and Bolinas Point
}

\begin{abstract}
Algal species cover and bare rock space (mean \pm 1 S.E.) in each treatment at Pescadero Point and Bolinas Point for each of the sampling dates analyzed (4, $8,12,16$ months). Only taxa/substrate that represented at least ten percent cover were analyzed and are presented here. A dash (-) represents a species not found in that particular treatment at that time. For all treatments, $n=4$.
\end{abstract}

Species abbreviations in tables are as follows:

$\begin{array}{lll}\text { "C "scabra } & = & \text { "Collisella" scabra } \\ L \text { digitalis } & = & \text { Lottia digitalis } \\ \text { L scutulata } & = & \text { Littorina scutulata } \\ T \text { funebralis } & = & \text { Tegula funebralis }\end{array}$




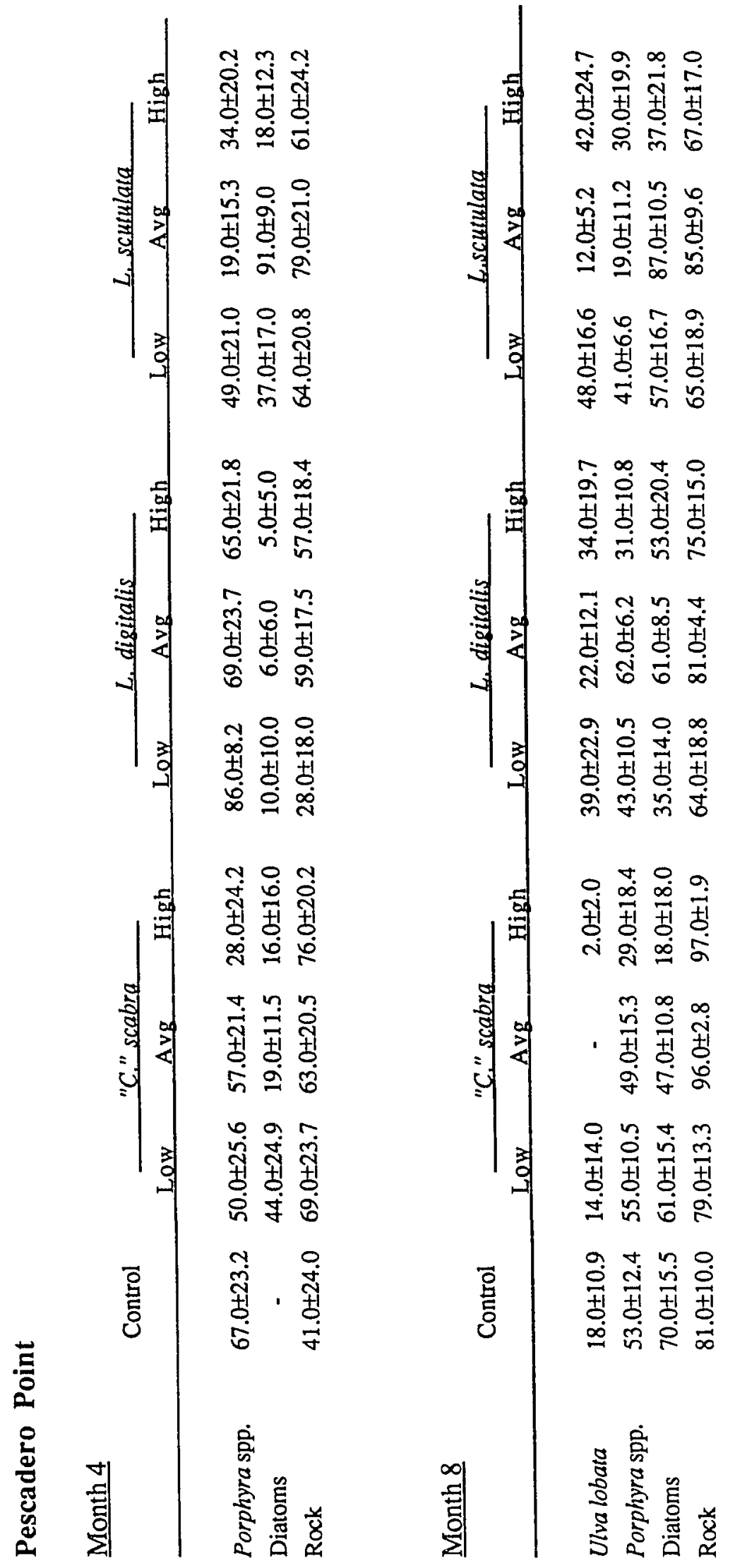




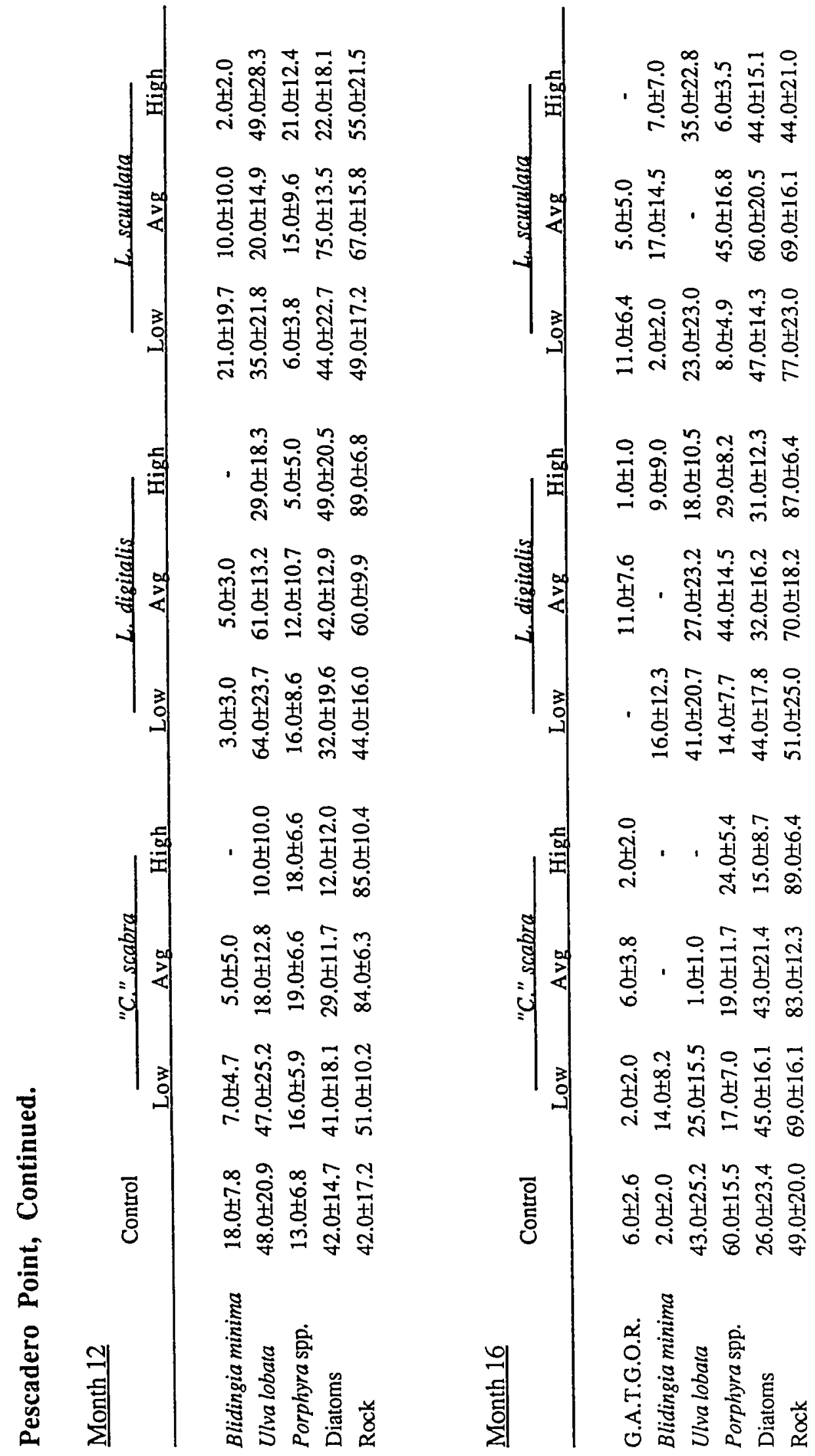




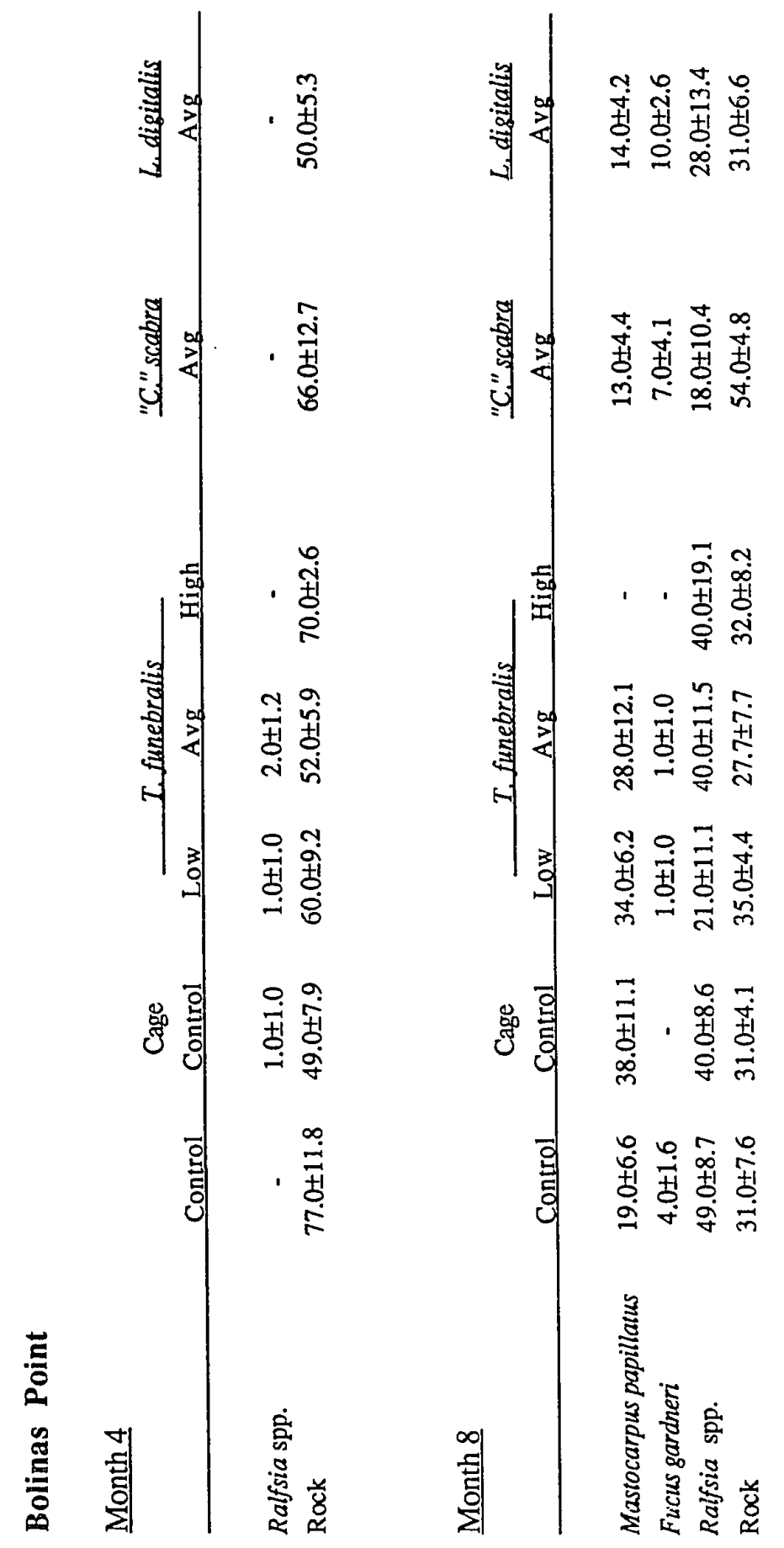




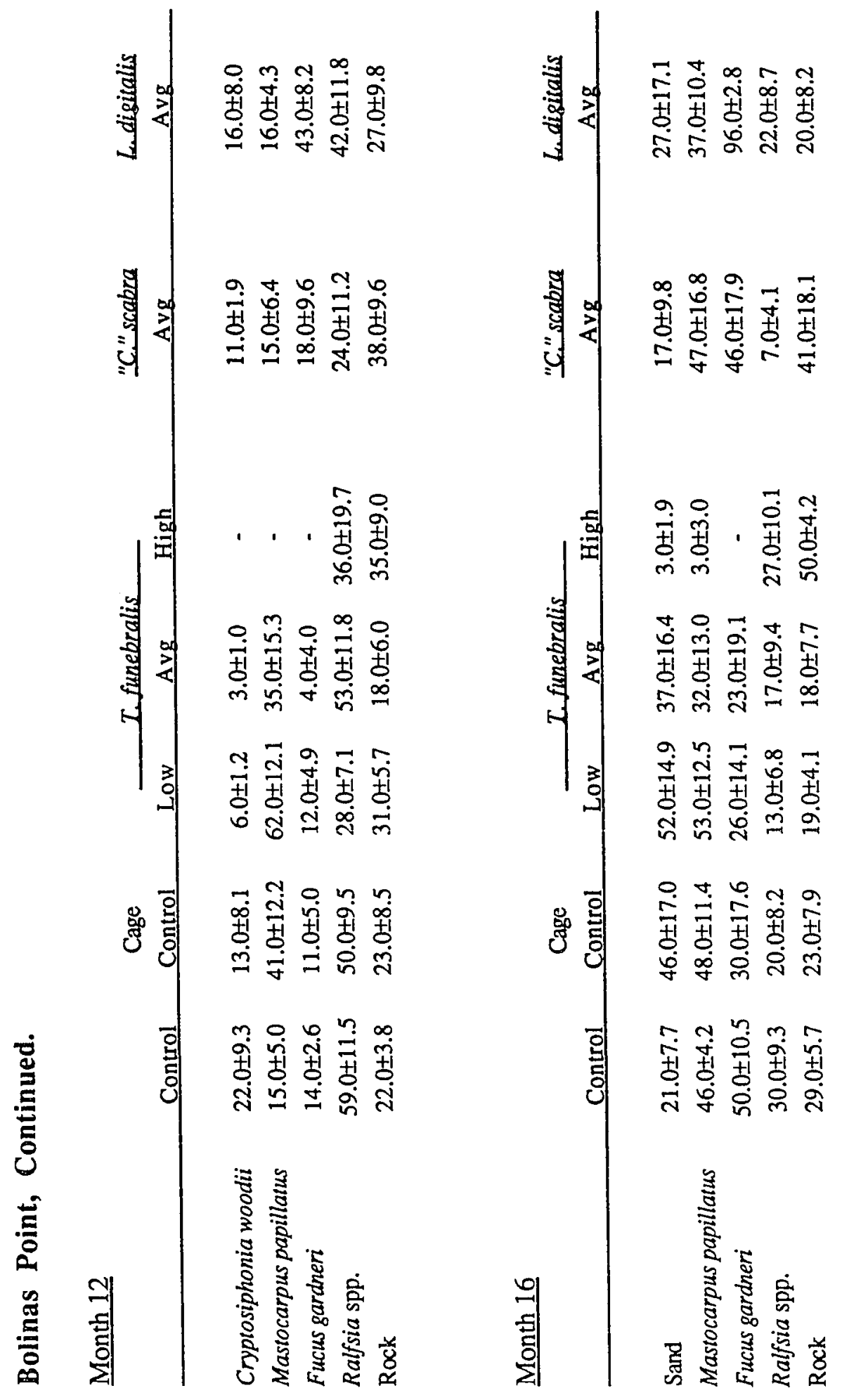




\section{APPENDIX 3}

\section{Grazer Densily \\ Results of the Multi-Site Study}

Grazer densities (mean $/ 0.1875 \mathrm{~m}^{2}$ plot) from the multi-site study are presented. Densities at each site and all sites combined in the spring-cleared and fall-cleared treatments for each grazer are given. Error is \pm 1 S.D. and $n=$ 3. The spring-cleared plots were cleared in March and April of 1985, and fallcleared plots in October and November of 1985. 


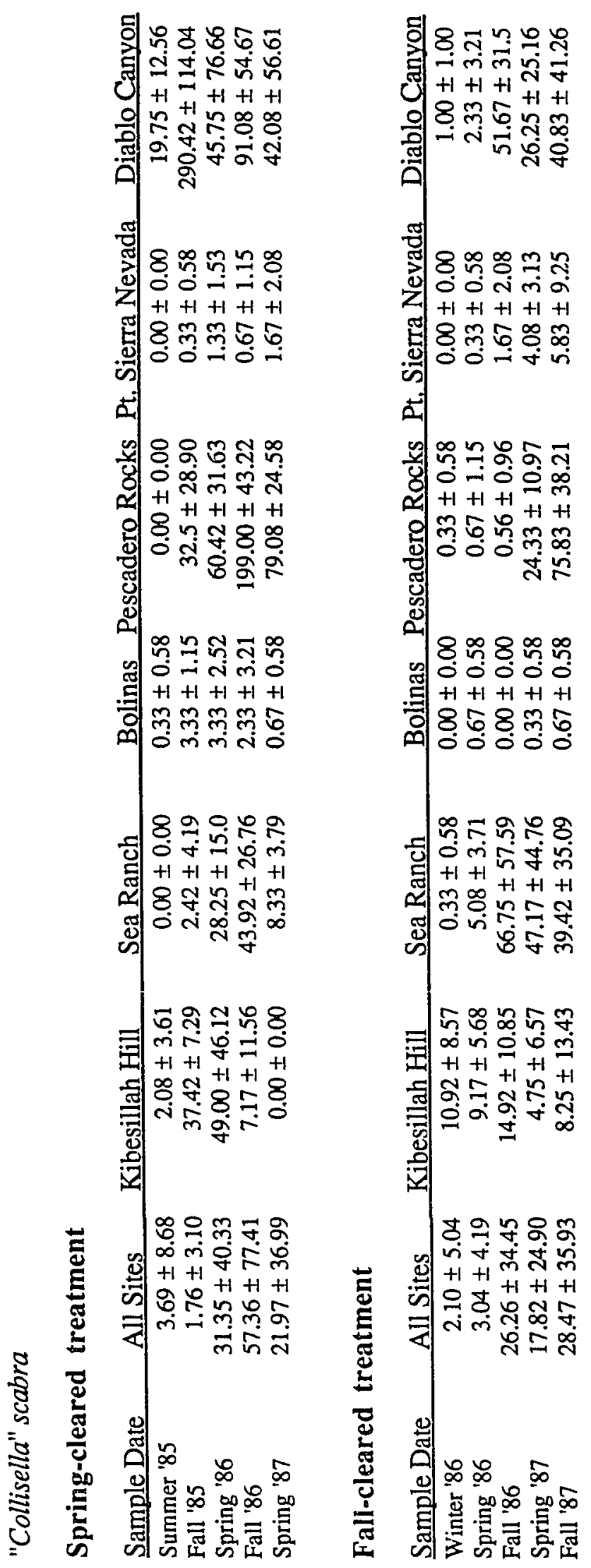




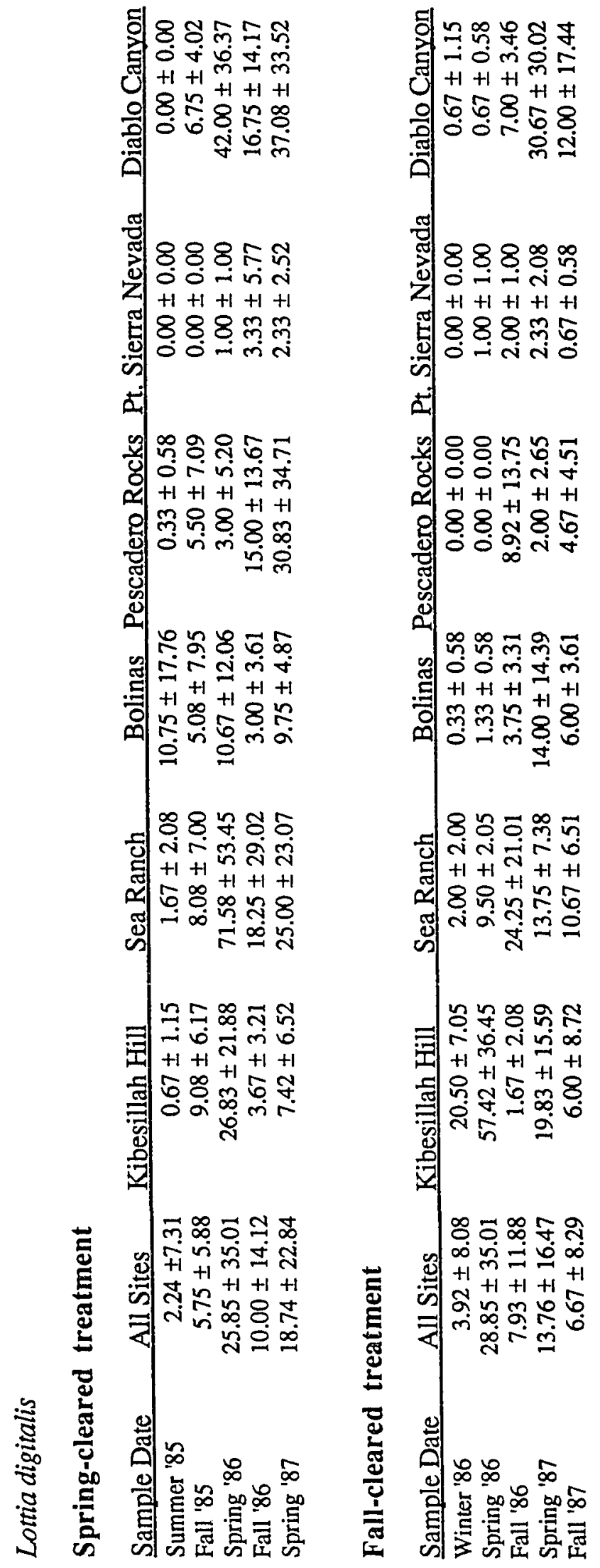




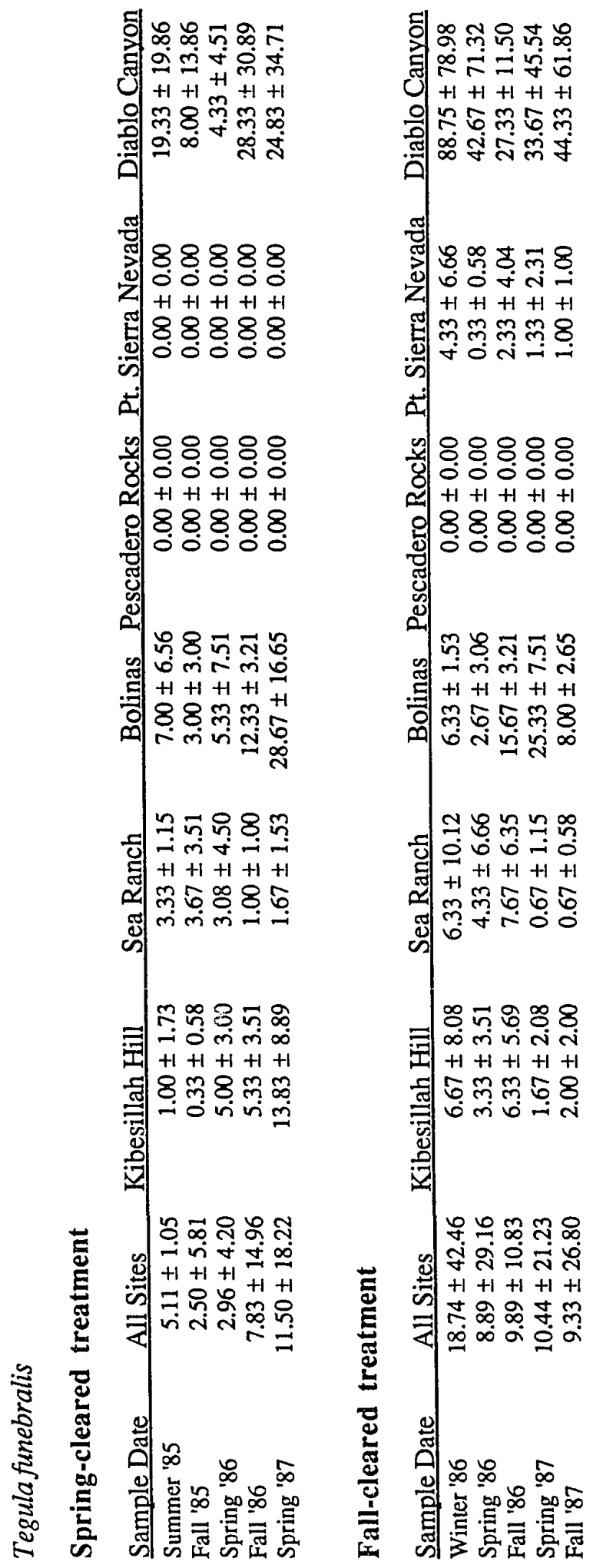




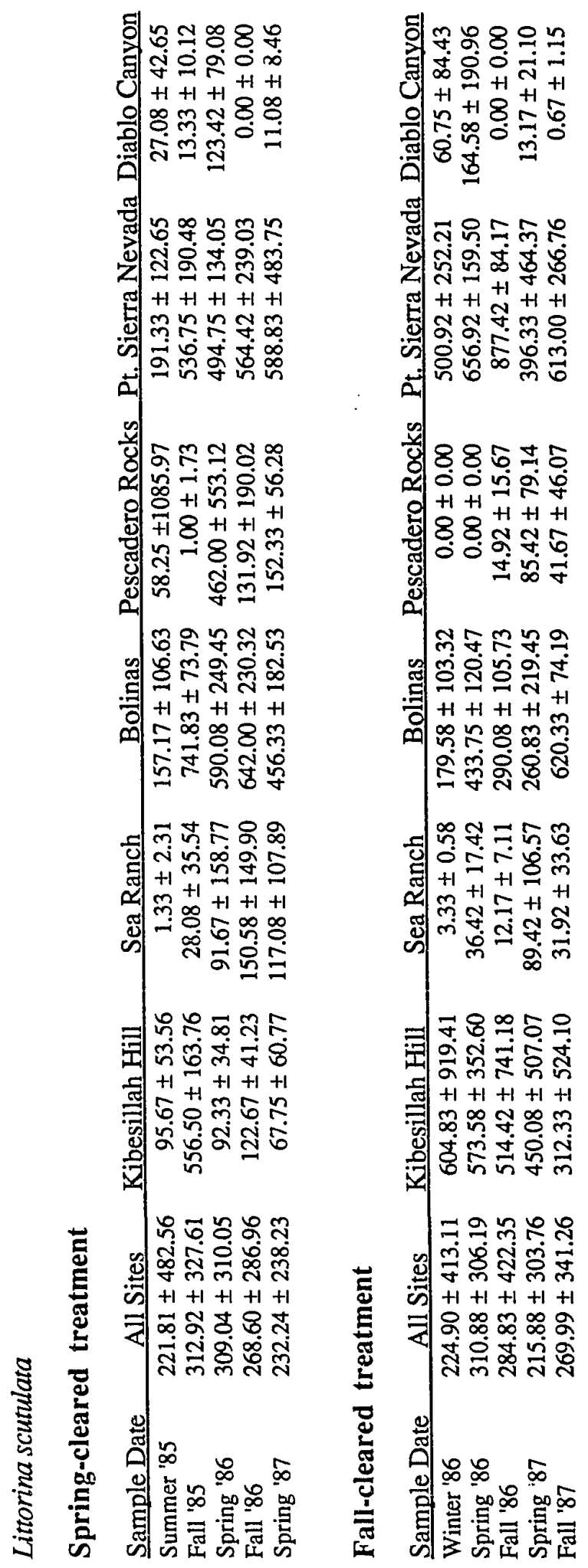

